Document downloaded from:

http://hdl.handle.net/10251/74907

This paper must be cited as:

Sadowska, K.; Góra-Marek, K.; Drozdek, M.; Kustrowski, P.; Datka, J.; Martínez-Triguero, J.; Rey Garcia, F. (2013). Desilication of highly siliceous zeolite ZSM-5 with $\mathrm{NaOH}$ and $\mathrm{NaOH} /$ tetrabutylamine hydroxide. Microporous and Mesoporous Materials. 168:195-205. doi:10.1016/j.micromeso.2012.09.033.

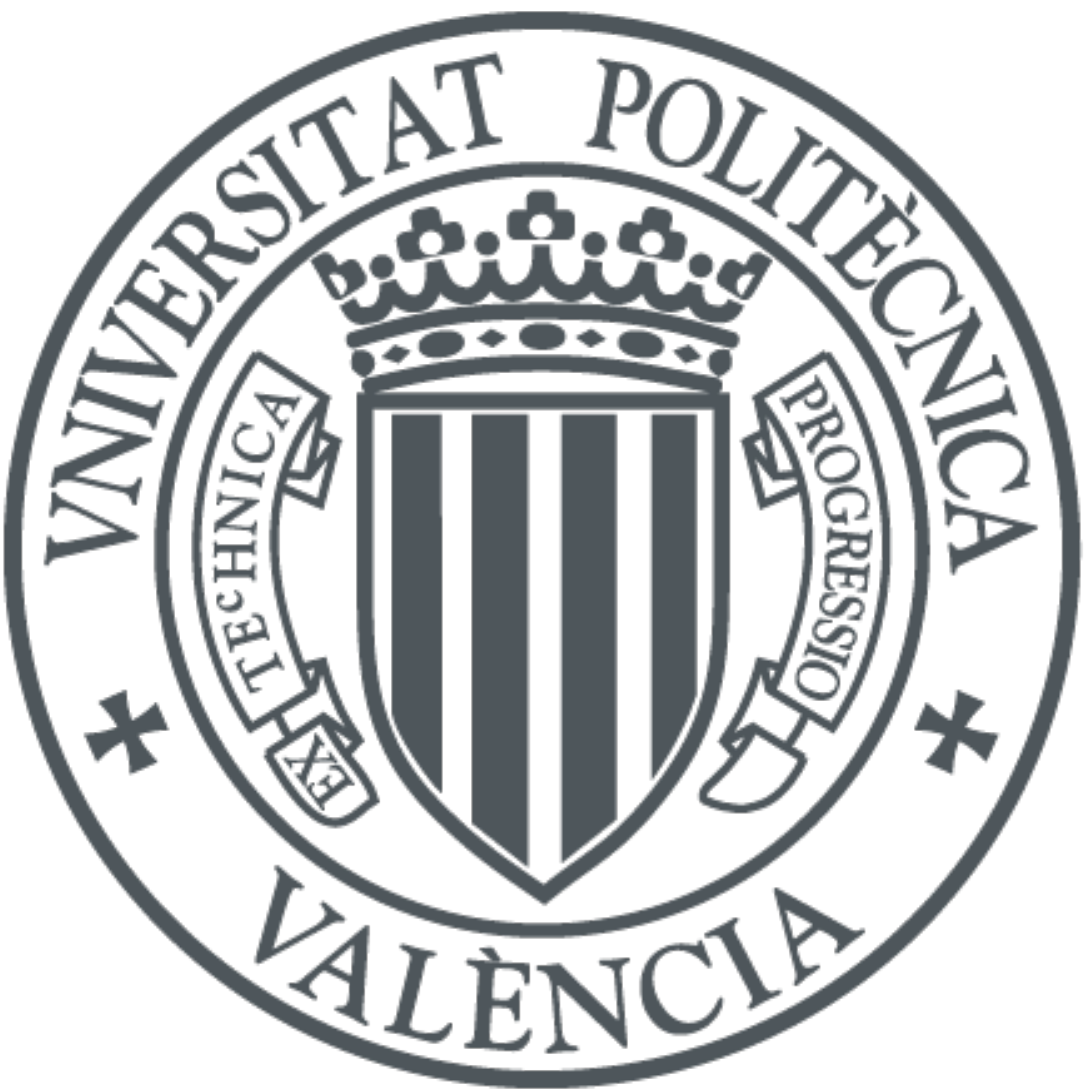

The final publication is available at

http://dx.doi.org/10.1016/j.micromeso.2012.09.033

Copyright Elsevier

Additional Information 


\title{
Desilication of highly siliceous zeolite ZSM-5 with $\mathrm{NaOH}$ and $\mathrm{NaOH} /$ tetrabutylamine hydroxide
}

\author{
K. Sadowska ${ }^{a}$, K. Góra-Mareka, M. Drozdeka ${ }^{a}$, P. Kuśtrowskia, J. Datka ${ }^{a}$, \\ J. Martinez-Triguero ${ }^{\mathrm{b}}, \mathrm{F}$. Rey ${ }^{\mathrm{b}}$
}

${ }^{a}$ Faculty of Chemistry, Jagiellonian University, Ingardena 3, 30-060 Krakow, Poland Phone +4812 6632081, email: gorak@chemia.uj.edu.pl

${ }^{b}$ Instituto de Tecnología Química, Universidad Politécnica de Valencia, Camino de Vera s.n., 46022 Valencia, Spain

\section{ABSTRACT}

The results of both chemical and XPS analysis pointed out that desilication of highly siliceous ZSM-5 of $\mathrm{Si} / \mathrm{Al}=164$ was more effective in the surface zone than in the bulk, contrary to zeolite ZSM-5 of Si/Al = 31.6. According to the IR studies in parent zeolite the concentration of protonic sites was very close to the concentration of $\mathrm{Al}$ indicating that all $\mathrm{Al}$ atoms can form Si-OH-Al. The results of our quantitative IR studies strongly support the realumination thesis, i.e. some $\mathrm{Al}$ atoms extracted in basic solutions are subsequently reinserted forming new acidic hydroxyls. In desilicated zeolites all $\mathrm{Al}$ atoms were able to form protonic sites, however part of them dehydroxylated during the activation of zeolite producing Lewis acid sites according to the stoichiometry: one protonic site was transformed into one Lewis site. Low temperature nitrogen adsorption revealed that the treatment of highly siliceous zeolite with $0.2 \mathrm{M} \mathrm{NaOH/TBAOH}$ mixture produced mesopores of smaller diameter and narrower pore size distribution than in the case of zeolite of medium Si/Al ratio. This result can be explained by low concentration of $\mathrm{Al}$ which similarly as $\mathrm{TBA}^{+}$cations plays the role of pore directing agents (PDA). Contrary to $\mathrm{TBA}^{+}$, the presence of $\mathrm{Al}$ in desilication mixture, led to the formation of larger pores. Therefore, in highly siliceous zeolite $\mathrm{TBA}^{+}$ played dominant role as PDA producing narrower pores. Highly siliceous zeolite with uniform distribution of relatively narrow pores may be useful catalyst or catalyst support. The influence of desilication temperature on porosity development was also investigated. The increase of desilication temperature from $338 \mathrm{~K}$ to $353 \mathrm{~K}$ resulted in both more extensive demetalation (more $\mathrm{Si}$ and $\mathrm{Al}$ is extracted) and the distinct increase of the volume and surface of mesopores. Both lower concentration of protonic sites and higher concentration of Lewis 
sites confirmed partial zeolite destruction upon desilication at elevated temperature. The experiments of pivalonitrile sorption followed by IR spectroscopy showed a significant increase of accessibility of acid sites to bulky pivalonitrile molecules.

\section{Introduction}

Zeolites are crystalline aluminosilicates with well defined micropore system; however their catalytic applicability is restricted by diffusional limitations. The diffusional constrains can be minimised by a controlled formation of intracrystalline mesopore system. Templating, dealumination and desilication are well known routes to induce the additional mesoporosity in zeolite particles. Porous carbon or carbon nanotubes as well as mesoscale cationic polymers are commonly used during templating methods [1-3]. Further modifications include synthesis of nanosized zeolite crystals, zeolitization of mesoporous materials and recrystallization [4]. To develop mesoporosity demetalation (dealumination and desilication), based on preferential aluminium or silicon extraction from zeolite framework, is tailored.

Desilication has been proven to be effective method to introduce mesoporosity in different types of zeolite structures [5-16]. Till now the majority of desilication studies has been done with zeolites of medium $\mathrm{Si} / \mathrm{Al}$ ratio (25-50) where aluminium acts as the pore directing agent regulating the extent of the $\mathrm{Si}$ extraction. In such case, $\mathrm{Al}$ removed from the zeolite framework during the desilication is proposed to be subsequently reinserted into the tetrahedral positions of mesopore walls forming acidic hydroxyls.

High silica zeolites still remain interesting subject in the search for new heterogeneous catalysts. Low concentration of acid sites and low hydrophility of these materials offer the application as less corrosive solid acid catalysis. The studies of desilication of highly siliceous zeolites have been less frequent, and such zeolites are a class of materials without efficient method of introducing extra mesoporosity. Desilication of silicalite-1 with tetrapropylammonium cation $\left(\mathrm{TPA}^{+}\right)$as a pore directing agent (PDA) and in the presence of aluminium nitrate has been also reported by Verboekend et al. [17]. Direct consequence of the presence of external $\mathrm{Al}$ source is surface $\mathrm{Al}$-enrichment indicating the realumination process. A model of desilication relating the affinity of zeolite surface to PDA and their efficiency in mesopores formation was also discussed.

IR spectroscopy employing probe molecules such as pyridines, hindered nitriles, and CO is widely applied to determine the acid properties (number and strength), and location of protonic sites in zeolites [18-24]. A powerful method to quantify the remarkably improved accessibility of acid sites in hierarchically structured zeolites (MFI, MOR) with alkylpyridines 
(lutidine: $0.67 \mathrm{~nm}$, collidine: $0.74 \mathrm{~nm}$ ) has been delivered by Thibault-Starzyk et al. [25]. The accessibility index (ACI), defined as the number of acid sites detected by adsorption of the probe molecule divided by the total amount of acid sites in the zeolite (calculated aluminum content), is a powerful tool to standardize acid site accessibility in zeolites.

The aim of this work was to investigate the influence of different conditions on desilication process of highly siliceous zeolite ZSM-5 (Si/Al=164). To follow the impact of desilication conditions on the composition of the surface zone and bulk, the chemical analysis and XPS measurements were performed. The formation of extra mesoporosity system was confirmed by low temperature sorption of nitrogen. The role of both $\mathrm{Al}$ and tetrabutylamine cations $\left(\mathrm{TBA}^{+}\right)$, as pore directing agents, on pore size distribution was discussed. FTIR studies provided information on the acid properties of the modified zeolites and accessibility of acid sites in the microporous/mesoporous materials. The concentration of both Brønsted and Lewis acid sites was measured in quantitative IR studies of pyridine sorption, the acid strength of Si-OH-Al was studied by low temperature experiments of $\mathrm{CO}$ sorption. The origin of Lewis acid sites was followed by $\mathrm{CO}$ and $\mathrm{NH}_{3}$ sorption. The information on the accessibility of both Brønsted and Lewis sites to bulky molecules was obtained by IR studies of pivalonitrile (trimethyl-acetonitrile) sorption. Catalytic properties of desilicated zeolites were followed in the cracking of $n$-decane (which penetrates the channels of zeolite ZSM-5) and 1,3,5-tri-isopropyl benzene (which does not enter the channels) and were correlated with acidity and accessibility of acid sites.

\section{Experimental}

\subsection{Catalyst preparation}

The parent ZSM-5 zeolite $(\mathrm{Si} / \mathrm{Al}=164)$ was provided by Zeolyst International $\left(\mathrm{NH}_{4}\right.$ form, CBV 28014). Desilication was carried out in the solutions of $\mathrm{NaOH}$ and the mixtures of $\mathrm{NaOH}$ and $\mathrm{TBAOH}$ (tetrabutylamine hydroxide) at temperatures of 338 and $353 \mathrm{~K}$ for $0.5 \mathrm{~h}$. The $100 \mathrm{ml}$ of solution was added to $3.0 \mathrm{~g}$ of zeolite. If desilication was done with $\mathrm{NaOH}$ only, 0.1 M, 0.2 M and 0.5 M solutions were used. The $\mathrm{NaOH} / \mathrm{TBAOH}$ mixtures had concentrations of $0.2 \mathrm{M}$ and $0.5 \mathrm{M}$. For the $0.2 \mathrm{M}$ mixture $\mathrm{TBAOH} /(\mathrm{NaOH}+\mathrm{TBAOH})$ ratios (denoted shortly as $\mathrm{R}$ ) were 0.1 and 0.4 , for the $0.5 \mathrm{M}$ solution $\mathrm{R}$ ratio was 0.1 . After desilication suspension was cooled down in ice-bath and filtered. At this stage the samples of collected filtrates were taken for the analysis. The hierarchically structured zeolites were washed with water until neutral $\mathrm{pH}$. Next a fourfold ion-exchange with $0.5 \mathrm{M} \mathrm{NH}_{4} \mathrm{NO}_{3}$ was 
performed at $333 \mathrm{~K}$ for $1 \mathrm{~h}$. Finally, the zeolites were again filtrated, washed and dried at room temperature.

Our previous studied exhibited that desilication with bases of the concentration higher than $0.5 \mathrm{M}$ resulted in significant destruction of zeolite and led to formation of protonic sites (not Si-OH-Al groups) of weak acid strength. Therefore, such materials of poor crystallinity are not presented herein.

\subsection{Characterization methods}

$\mathrm{Si}$ and $\mathrm{Al}$ concentrations in the parent and desilicated zeolites as well as in filtrates were determined by the ICP OES method with an Optima 2100DV (PerkinElmer) spectrometer.

The powder X-ray diffraction (XRD) measurements were carried out using a PANalytical Cubix diffractometer, with $\mathrm{CuK}_{\alpha}$ radiation, $\lambda=1.5418 \AA$ and a graphite monochromator in the $2 \theta$ angle range of $2-40^{\circ}$. X-ray powder patterns were used for structural identification of the relative crystallinity value (\%Cryst) for all the zeolites. The determination of the relative crystallinity value was based on the intensity of the characteristic peaks in the range between $22.5^{\circ}$ to $25.0^{\circ}$.

The X-ray photoelectron spectra (XPS) were measured with a Prevac photoelectron spectrometer equipped with a hemispherical VG SCIENTA R3000 analyzer. The photoelectron spectra were measured using a monochromatized aluminum $\mathrm{AlK} \alpha$ source ( $E=1486.6 \mathrm{eV}$ ) and a low energy electron flood gun (FS40A-PS) to compensate the charge on the surface of nonconductive samples. The base pressure in the analysis chamber during the measurements was $5 \cdot 10^{-9}$ mbar. Spectra were recorded with constant pass energy of $100 \mathrm{eV}$ for the survey and for high resolution spectra. The binding energies were referenced to the Si 2p core level $(103.0 \mathrm{eV})$. The composition and chemical surrounding of the sample surface were investigated on the basis of the areas and binding energies of $\mathrm{Al} 2 \mathrm{p}, \mathrm{Si} 2 \mathrm{p}$ and $\mathrm{O}$ 1s photoelectron peaks. The fitting of high resolution spectra was provided through the CasaXPS software.

For the FTIR study all samples were pressed into the form of self-supporting wafers (ca. $5 \mathrm{mg} / \mathrm{cm}^{2}$ ) and activated in situ in an IR cell at $820 \mathrm{~K}$ under vacuum for $1 \mathrm{~h}$. Spectra were recorded with the resolution of $2 \mathrm{~cm}^{-1}$ by using a Bruker Equinox 55 spectrometer equipped with a MCT detector.

The $\mathrm{N}_{2}$ adsorption and desorption processes at $77 \mathrm{~K}$ were studied on an ASAP 2010 Micromeritics after activation in vacuum at $620 \mathrm{~K}$ for $12 \mathrm{~h}$. The $t$-plot method with the Harkins-Jura reference isotherm was used to determine the micropore volume $\left(\mathrm{V}_{\text {micro }}\right)$. Pore 
size distribution was obtained by the BJH model following the adsorption branch of the isotherm. The same model was applied for the calculation of surface area $\left(\mathrm{S}_{\text {meso }}\right)$ and volume ( $\mathrm{V}_{\text {meso }}$ ) of mesopores. The mesopore surface area was calculated in the range between 2 and $50 \mathrm{~nm}$ with BJH model and it denotes external surface area.

\subsection{Catalytic tests}

n-Decane and 1,3,5-tri-isopropyl benzene (TIPB) cracking experiments were performed at $773 \mathrm{~K}$ and for $60 \mathrm{~s}$ time on stream in a microactivity test unit as described previously [26]. Pellets of zeolites were crushed and sieved, fraction of the 0.59 to $0.84 \mathrm{~mm}$ was taken. For $n$-decane cracking $0.2 \mathrm{~g}$ of catalyst was diluted in $2.5 \mathrm{~g}$ of inert silica, whereas the TIPB cracking was performed without diluting $0.3 \mathrm{~g}$ of the catalysts in silica matrix. For each catalyst, four experiments were performed, maintaining the amount of catalyst (cat) constant and varying the $n$-decane and TIPB amounts (oil).

Kinetic rate constants were calculated by fitting the conversions (X) to a first-order kinetic equation for a plug flow reactor (1), assuming that the deactivation is enclosed in the kinetic constant and taking into account the volumetric expansion factor (2),

$$
\begin{aligned}
& \mathrm{K}=-\left(\text { cat oil }^{-1} \mathrm{TOS}\right)^{-1}[\varepsilon \mathrm{X}+(1+\varepsilon) \ln (1-\mathrm{X})] \\
& \varepsilon=(\text { Emolar selectivities of products })-1
\end{aligned}
$$

We used these rate constants to compare the activities of the catalysts with their textural and acidic properties.

\section{Results and Discussion}

\subsection{Chemical analysis of bulk and surface}

The XRD analysis (see Supplementary data) demonstrated that desilication at mild conditions (0.1 $\mathrm{M}$ and $0.2 \mathrm{M} \mathrm{NaOH}$ or $\mathrm{NaOH} / \mathrm{TBAOH})$ practically did not disturb the crystallinity of resulting materials (Table 1 and 2), the zeolite structure was preserved (crystallinity decreased from $100 \%$ to $85 \%$ ). On the other hand, treatment with $0.5 \mathrm{M}$ bases caused noticeable loss of crystallinity - the values of relative crystallinity drop to $64 \%$ for pure $\mathrm{NaOH}$ treatment.

The values of $\mathrm{Si} / \mathrm{Al}$ ratio for the parent and desilicated with $\mathrm{NaOH}$ zeolites obtained from chemical analysis are presented in Table 1 . They decrease with $\mathrm{NaOH}$ concentration as a result of more extensive desilication. The analysis of filtrate showed that the $\mathrm{NaOH}$ treatment led also to some $\mathrm{Al}$ extraction. The amount of extracted $\mathrm{Al}$ atoms was relatively small (4-5 \%) for diluted $(0.1$ and $0.2 \mathrm{M}) \mathrm{NaOH}$, however it was substantial when zeolite was treated with $0.5 \mathrm{M} \mathrm{NaOH}$ (loss of $73 \% \mathrm{Al}$ ). Evident $\mathrm{Al}$ extraction is supposed to be the result of 
dissolving the large fragments of zeolite grains. These results are consistent with XRD data exhibiting vital loss of crystallinity hierarchically structured materials obtained by the treatment with $0.5 \mathrm{M}$ bases.

To answer the question if desilication was more effective from the zeolite surface or

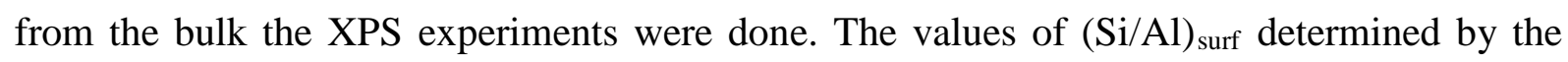
XPS experiments are presented in Table 1 . The values of the (Si/Al) surf $/(\mathrm{Si} / \mathrm{Al})_{\text {bulk }}$ factor were calculated to evaluate the influence of desilication on the distribution of silicon and aluminum in zeolite grains. For parent zeolite $(\mathrm{Si} / \mathrm{Al})_{\text {surf }} /(\mathrm{Si} / \mathrm{Al})_{\text {bulk }}$ factor was 0.82 indicating a deficiency of Si i.e. an excess of $\mathrm{Al}$ in the surface zone, compared to the bulk phase. Surface zone enrichment in $\mathrm{Al}$ and Si excess in the bulk was reported by several authors e.g. [27,28]. The treatment of zeolite with $\mathrm{NaOH}$ resulted in a decrease of ( $\mathrm{Si} / \mathrm{Al})_{\text {surf }} /(\mathrm{Si} / \mathrm{Al}$ ) bulk factor (to 0.41 for zeolite treated with $0.5 \mathrm{M} \mathrm{NaOH}$ ) indicating that the deficiency of $\mathrm{Si}$ and an excess of $\mathrm{Al}$ in the surface zone (the extraction of $\mathrm{Si}$ atoms was more effective from the surface zone) becomes gradually essential. This result indicates also that etching of zeolite by $\mathrm{OH}^{-}$starts on the crystal surface. It is worth noticing that for zeolite of lower Si/Al (31.6) desilication was more effective from the bulk [15], what was explained by the excess of $\mathrm{Al}$ on the surface and the protection of neighboring $\mathrm{Si}$ by negative charge of $\mathrm{AlO}_{4}^{-}$against $\mathrm{OH}^{-}$attack. In highly siliceous zeolite of $\mathrm{Si} / \mathrm{Al}=164$ the concentration of $\mathrm{Al}$ was so low that even some excess of $\mathrm{Al}$ in surface zone was not sufficient to ensure the protection of surface $\mathrm{Si}$ atoms from $\mathrm{OH}^{-}$ attack.

The treatment of zeolite with $0.2 \mathrm{M} \mathrm{NaOH/TBAOH}$ mixture caused less extensive demetalation than with $\mathrm{NaOH}$ (cf. Table 2). The amounts of both $\mathrm{Si}$ and $\mathrm{Al}$ extracted during desilication were a half of those obtained for $0.2 \mathrm{M} \mathrm{NaOH}$ only. This can be explained by protection of zeolite surface by $\mathrm{TBA}^{+}$cations against $\mathrm{OH}^{-}$attack. Similar effects were reported by Perez-Ramirez et al. [29] for desilication with a $\mathrm{NaOH} /$ tetrapropylamine hydroxide mixture and were also observed in our previous study [15] for zeolite ZSM-5 of lower $\mathrm{Si} / \mathrm{Al}=31.6$.

As mentioned above, the treatment of zeolite of $\mathrm{Si} / \mathrm{Al}=164$ with $0.5 \mathrm{M} \mathrm{NaOH}$ resulted in a massive dissolution of zeolite grains and substantial loss of both $\mathrm{Si}$ and $\mathrm{Al}$ atoms. For $0.5 \mathrm{M} \mathrm{NaOH/TBAOH}$ mixture less significant demetalation was observed in comparison with $\mathrm{NaOH}$ only. According to the data presented in Table 2 the extraction of $\mathrm{Si}$ and $\mathrm{Al}$ atoms from the zeolite framework treated with $0.5 \mathrm{M} \mathrm{NaOH/TBAOH}$ mixture was less pronounced than from zeolite desilicated with $\mathrm{NaOH}$ only. More substantial Si extraction suggests that in 
concentrated basic solutions $\mathrm{TBAOH}$ protects zeolite rather against removal of $\mathrm{Al}$ than against Si extraction.

Along with the data presented in Table 2 the $(\mathrm{Si} / \mathrm{Al})_{\text {surf }} /(\mathrm{Si} / \mathrm{Al})_{\text {bulk }}$ values for the zeolites treated with $\mathrm{NaOH} / \mathrm{TBAOH}$ mixtures were higher than for pure $\mathrm{NaOH}$ indicating less extensive desilication of surface zone of zeolite, due to the protection of surface by $\mathrm{TBA}^{+}$ cations.

\subsection{Acid properties of desilicated zeolites}

\subsubsection{The $\mathrm{OH}$ groups analysis}

The first information on acidity of desilicated zeolites was obtained by the scrutiny of the spectra of $\mathrm{OH}$ groups (Fig. $1 \mathrm{~A}-\mathrm{C}$ ). The spectra show three bands: the $3740 \mathrm{~cm}^{-1}$ band of $\mathrm{Si}-\mathrm{OH}$ on external surfaces of zeolitic crystals and/or mesopore walls, the shoulder at 3730 $\mathrm{cm}^{-1}$ of Si-OH in the defects, and the $3610 \mathrm{~cm}^{-1}$ band of the acidic Si-OH-Al hydroxyls. The treatment with diluted $0.1 \mathrm{M}$ and $0.2 \mathrm{M} \mathrm{NaOH}$ (Fig. $1 \mathrm{~A}$ ) resulted in an vital increase of 3740 $\mathrm{cm}^{-1}$ band of Si-OH groups on mesopores walls parallel to the increase of mesopore volume (see Section 3.3 and Table 3). The band of acidic hydroxyls almost did not change. The desilication in more concentrated $\mathrm{NaOH}(0.5 \mathrm{M})$ results in a further increase of the Si-OH band (due to enhancement of mesopore surface) and in a slight decrease in the intensity of the $\mathrm{Si}-\mathrm{OH}-\mathrm{Al}$ band, despite of a distinct increase of $\mathrm{Al}$ content (decrease of $\mathrm{Si} / \mathrm{Al}$ - see Table 1). This phenomenon can be explained by partial amorphisation of zeolite due to massive extraction of framework $\mathrm{Si}$ and $\mathrm{Al}$ which was evidenced by XRD results (see Supplementary data).

\subsubsection{Brønsted acid sites in desilicated ZSM-5}

The concentration of both Brønsted and Lewis acid sites was determined in quantitative IR studies of pyridine sorption according to procedure described in our previous paper [30]. The acid sites concentration was compared to the concentration of Al calculated from chemical analysis (Tables 1 and 2). In parent zeolite the concentration of protonic sites determined by IR was found to be very close to the concentration of $\mathrm{Al}$ determined by chemical analysis (85 and $94 \mu \mathrm{mol} / \mathrm{g}$ ). The concentration of Lewis acid sites was very low (6 $\mu \mathrm{mol} / \mathrm{g}$ ) indicating that nearly all $\mathrm{Al}$ atoms were in framework positions being able to form acidic Si-OH-Al groups. In zeolites desilicated with diluted base (0.1 M and 0.2 M NaOH and $\mathrm{NaOH} / \mathrm{TBAOH}$ ) the concentration of protonic sites was lower (by 20-40\%) than concentration of Al. Some Lewis acid sites are present and their concentration increases with the concentration of desilicating solutions. The treatment of zeolite with more concentrated $\mathrm{NaOH}(0.5 \mathrm{M})$ resulted in more extensive desilication. Total concentration of $\mathrm{Al}$ increased 
significantly, however the concentration of protonic sites was found to be two times lower than the $\mathrm{Al}$ concentration determined in chemical analysis, and additionally important amounts of Lewis acid sites were formed.

According to the data presented in Fig. 1 the intensity of the Si-OH-Al band at 3610 $\mathrm{cm}^{-1}$ decreased slightly (if comparing with parent zeolite) upon the treatment of zeolite with $0.5 \mathrm{M} \mathrm{NaOH}$, even though the concentration of protonic sites $(150 \mu \mathrm{mol} / \mathrm{g})$ was higher than in parent zeolite (88 $\mu \mathrm{mol} / \mathrm{g})$. It suggests that some $\mathrm{Al}$ atoms are in extraframework amorphous material but they are able to create protonic sites. Therefore, in zeolite desilicated in relatively concentrated $\mathrm{NaOH}$ (e.g. $0.5 \mathrm{M}$ ) three types of $\mathrm{Al}$ atoms can be distinguished: part of $\mathrm{Al}$ atoms is located in framework tetrahedral positions and can form typical zeolitic Si-OH-Al groups (IR band $3610 \mathrm{~cm}^{-1}$ ), others are situated in amorphous material and can also form acidic sites (but not characterized by IR band at $3610 \mathrm{~cm}^{-1}$ ). The third type of $\mathrm{Al}$ atoms forms Lewis acid sites. The origin of Lewis acid sites in desilicated zeolites will be discussed in the Section 3.2.4.

\subsubsection{The acid strength of hierarchical ZSM-5 zeolite}

The information on the acid strength of $\mathrm{Si}-\mathrm{OH}-\mathrm{Al}$ groups was obtained in low temperature experiments of $\mathrm{CO}$ sorption. The $\Delta v$ values of hydroxyls engaged in hydrogen bonding with CO decrease with the extent of desilication (Table 1 and Table 2) pointing to the decrease of the acid strength. Similarly, the same effect was reported for desilicated ZSM-5 zeolite with $\mathrm{Si} / \mathrm{Al}=31.6$ [30]. It has been found that the decrease of the acid strength resulted from extraction of $\mathrm{Al}$ atoms forming the most acidic $\mathrm{Si}-\mathrm{OH}-\mathrm{Al}$. It is possible, that such $\mathrm{Al}$ which creates most acidic Si-OH-Al is the less stable in zeolite framework and is removed in the first order. It seems that similar interpretation can be also applied also to highly siliceous ZSM-5 followed in this study.

\subsubsection{Lewis acid sites in desilicated zeolites}

The origin of Lewis acid sites in desilicated zeolites will be now discussed. This problem was studied by the low temperature sorption of carbon monoxide (which detects Lewis sites and informs on their nature) and ammonia (which measures total concentration of protonic sites). The spectra of $\mathrm{CO}$ sorbed at $170 \mathrm{~K}$ in non-desilicated (parent) zeolite (A) as well as zeolites desilicated at mild conditions (0.2 M NaOH/TBAOH - B) and in severe conditions (0.5 M NaOH/TBAOH - C) are presented in Fig. 2. Carbon monoxide was sorbed in zeolites dehydrated at $450 \mathrm{~K}$ (spectra a) and also in zeolites activated at vacuum at $820 \mathrm{~K}$ (spectra b). The band at $2230 \mathrm{~cm}^{-1}$ in the spectra of CO sorbed in desilicated zeolites activated at $820 \mathrm{~K}$ is the evidence of the presence of Lewis acid sites produced by dehydroxylation of 
protonic sites during activation of desilicated zeolites (Fig. 2 B, C, spectra b). On the other hand, Lewis sites were absent in non-desilicated zeolites (Fig. 2 A, spectrum b) and also in all the zeolites which were only dehydrated by evacuation at $450 \mathrm{~K}$, but not activated (spectra a).

Dehydroxylation reduces the concentration of protonic sites; therefore the information on the concentration of these sites was obtained from the intensity of the $1460 \mathrm{~cm}^{-1}$ band of ammonium ions. The spectra of the ammonium ions both in the zeolites dehydrated only (spectra a) and activated at $820 \mathrm{~K}$ (followed by saturation of all acid sites by ammonia at 380 $\mathrm{K}$ and subsequent evacuation at the same temperature) are presented in Fig. $2 \mathrm{~A}-\mathrm{C}$ (spectra a and b, respectively). The intensities of the ammonium ion bands in parent zeolite both dehydrated only and in activated one are the same (Fig. 2 A), what matches the absence of Lewis sites (absence of CO band at $2230 \mathrm{~cm}^{-1}$ ) and indicates that activation of non-desilicated zeolite did not cause any dehydroxylation. On the other hand, activation at vacuum at $820 \mathrm{~K}$ of desilicated zeolites (Fig. 2 B and C) resulted not only in the formation of the $\mathrm{Si}-\mathrm{OH}-\mathrm{Al}$ groups (by decomposition of ammonium ions) but also in condensation of these sites (dehydroxylation) leading to the formation of Lewis sites. This effect is more pronounced in zeolite desilicated in severe conditions (0.5 M NaOH/TBAOH): the loss of intensity of band at $1460 \mathrm{~cm}^{-1}$ was substantial and the intensity of $2230 \mathrm{~cm}^{-1}$ band of CO interacting with Lewis sites was twice higher than for zeolite desilicated at mild conditions (0.2 M NaOH/TBAOH).

The concentration of ammonium ions was calculated from the intensity of $1460 \mathrm{~cm}^{-1}$ band and its extinction coefficient $\left(0.11 \mathrm{~cm}^{2} / \mu \mathrm{mol}\right)$ [31]. The concentration of $\mathrm{NH}_{4}{ }^{+}$ions in zeolites dehydrated and activated is presented in Table 4 together with the concentration of $\mathrm{Al}$ determined by chemical analysis. In zeolites dehydrated the concentration of $\mathrm{NH}_{4}{ }^{+}$ions was equal to the concentration of $\mathrm{Al}$ atoms determined in chemical analysis. It indicates that all $\mathrm{Al}$ atoms were in framework tetrahedral positions and the negative charge of $\mathrm{AlO}_{4}{ }^{-}$is neutralized by $\mathrm{NH}_{4}{ }^{+}$. It concerns both parent zeolite and zeolites desilicated at mild as well as severe conditions.

The treatment of zeolites at $820 \mathrm{~K}$ (activation) results in the decomposition of ammonium ions and formation of protonic sites, however some of these protonic sites dehydroxylate producing Lewis acid sites. The loss of the ammonium ions represents the amount of protonic sites lost by the dehydroxylation during the activation. According to the data presented in Table 4 the amount of protonic sites lost by dehydroxylation is the same as the amount of Lewis acid sites formed (determined in pyridine sorption experiments - see Table 2). This agreement confirms that the stoichiometry of dehydroxylation is 1:1 i.e. one protonic site lost produces one Lewis site. According to the data presented in Tables 1, 2, and 
6 the sum of the amounts both Lewis and protonic acid sites is comparable to the amount of $\mathrm{Al}$. It can be anticipated that all Al atoms in hierarchically structured zeolite ZSM-5 are able to form protonic sites; however some of these sites dehydroxylate easily forming Lewis acid sites. The stoichiometry observed for protonic sites in desilicated zeolites was found to be always $1: 1$ and to be different from dehydroxylation of typically zeolitic $\mathrm{Si}-\mathrm{OH}-\mathrm{Al}$ groups where two zeolitic Si-OH-Al condensate forming one Lewis acid site and water molecule [32, 33]. It should be noted, that the same stoichiometry of dehydroxylation (1:1) was reported for amorphous aluminosilicates (MCM-41, MCM-48 and others) [34].

Groen et al. [35] postulated that most of Al extracted from zeolite in alkaline solutions can be reinserted into framework positions near mesopore surfaces. The results of our quantitative IR studies strongly support the realumination thesis [35] evidencing the same amount of protonic sites as of $\mathrm{Al}$ atoms from chemical analysis, even in zeolite desilicated in severe conditions i.e. in $0.5 \mathrm{M} \mathrm{NaOH} / \mathrm{TBAOH}$. The reinserted on mesopores surface $\mathrm{Al}$ atoms are believed to form protonic sites which are more prone to dehydroxylation than typically zeolitic $\mathrm{Si}-\mathrm{OH}-\mathrm{Al}$ groups. The protonic sites rebuilt from reinserted $\mathrm{Al}$ atoms are supposed to behave as protonic sites on the surface of amorphous aluminosilicates.

\subsection{Porosimetric studies}

The treatment of zeolite with $\mathrm{NaOH}$ resulted in the formation of mesopores. The values of the mesopore surface and volume are presented in Table 3. Both mesopore surface and volume increase upon desilication. The volume of micropores practically did not change even in relatively concentrated $(0.5 \mathrm{M} \mathrm{NaOH})$ solution which caused massive dissolution of zeolite grains and loss of $93 \%$ of $\mathrm{Si}$ and $73 \%$ of $\mathrm{Al}$. This result seems to be surprising because for zeolite of $\mathrm{Si} / \mathrm{Al}=31.6$ desilicated with $0.5 \mathrm{M} \mathrm{NaOH}$ less extensive demetalation (extraction of $68 \%$ of $\mathrm{Si}$ and $18 \%$ of $\mathrm{Al}$ extraction) caused a significant loss of microporosity (from $0.105 \mathrm{~cm}^{3} / \mathrm{g}$ in parent zeolite to $0.062 \mathrm{~cm}^{3} / \mathrm{g}$ in desilicated one) [15]. It can be assumed that in highly siliceous zeolite (of Si/Al = 164) larger fragments of zeolite grains are dissolved or became amorphous. Nevertheless, the remaining fragments of zeolite preserve microporosity.

The pore size distributions determined by using BJH model are presented in Fig. 3. The treatment of zeolite with $0.1 \mathrm{M} \mathrm{NaOH}$ produced mesopores of relatively narrow diameter distribution centred at ca. $8 \mathrm{~nm}$. More concentrated $\mathrm{NaOH}(0.2 \mathrm{M})$ produced mesopores of various diameters; however a broad maximum in diameter distribution at ca. $10 \mathrm{~nm}$ can be seen. Furthermore, higher concentration of $\mathrm{NaOH}(0.5 \mathrm{M})$ led to the formation of mesopores with diameters between 5 and $50 \mathrm{~nm}$ and a maximum at ca. $15 \mathrm{~nm}$. By summing up, the data 
presented in Table 3 and Fig. $3 \mathrm{~A}$, one can state, that more concentrated $\mathrm{NaOH}$ is, mesopores of increasing volume and diameter are formed.

The addition of $\mathrm{TBAOH}$ to $\mathrm{NaOH}$ results in distinct modification of mesopore size, but without substantial modification of pore volume and specific surface area (Figs. $3 \mathrm{~B}$, C and Table 5). In zeolites treated with $0.2 \mathrm{M} \mathrm{NaOH/TBAOH}$ mixture relatively narrow pores with narrow diameter distribution with the maximum at ca. 4-5 nm were formed (Fig. 3B). There was no significant difference in pore distributions for the materials treated with $0.2 \mathrm{M}$ $\mathrm{NaOH} / \mathrm{TBAOH}$ mixtures at various proportions between both bases. However, the treatment of zeolite with $0.5 \mathrm{M} \mathrm{NaOH} / \mathrm{TBAOH}$ mixture resulted in a wider pore size distribution (Fig. 3C). Contrary to the zeolite treated with pure $0.5 \mathrm{M} \mathrm{NaOH}$ where the pores larger than $15 \mathrm{~nm}$ were formed, the treatment in the presence of $\mathrm{TBAOH}$ leads to that generation of pores with diameter less than $15 \mathrm{~nm}$.

According to the data presented in Fig. $3 \mathrm{~B}$ desilication of zeolite of Si/Al $=164$ with $0.2 \mathrm{M} \mathrm{NaOH} / \mathrm{TBAOH}$ mixture resulted in the formation of mesopores of relatively narrow diameters and narrow pore size distribution. Larger pores with broad size distribution were obtained when the same zeolite was treated with pure $\mathrm{NaOH}$, or when zeolite of higher $\mathrm{Al}$ content $(\mathrm{Si} / \mathrm{Al}=31.6)$ was treated with $\mathrm{NaOH} / \mathrm{TBAOH}$ mixture [15] - Fig. $3 \mathrm{~B}$, curve marked with asterisk. Therefore, narrow pores and narrow pore size distribution were formed in highly siliceous zeolite treated with $\mathrm{NaOH}$ in the presence of amine hydroxide.

In order to explain the role of amine hydroxide and the effect of $\mathrm{Al}$ content in zeolite (i.e. Si/Al) on the mesopores formation the problem of pore-directing agents (PDA) will be now discussed. According to literature [17], both Al (extracted from zeolite framework) and amine cations can play the role of PDA. They protect zeolite grains surface against $\mathrm{OH}^{-}$ion attack and the massive zeolite dissolution. Verboekend and Perez-Ramirez [17] reported that larger pores were observed in the presence of $\mathrm{Al}$ in desilicating solution, whereas narrow pores were formed with amine hydroxides as PDA. It explains why several authors (e.g. refs. 36) reported the presence of narrow pores when desilication was done with the mixture of amine hydroxide and $\mathrm{NaOH}$. As highly siliceous zeolite $(\mathrm{Si} / \mathrm{Al}=164)$ was used in our study, the concentration of $\mathrm{Al}$ extracted into solution was negligible and amine cation played the role of the main PDA, producing narrow pores in zeolite.

All these findings indicate that the method of producing hierarchical zeolites with both narrow pores and narrow pore size distribution should be based on treatment of highly siliceous zeolite with the $\mathrm{NaOH}$ /amine hydroxide mixture. Pores in the lower nanometric size range [35] provide adequate transport characteristics to and from active sites with only 
moderate zeolite dissolution. Therefore, such materials can be used either as supports or as catalysts.

\subsection{Effect of temperature}

All the desilication experiments described above were carried out at $338 \mathrm{~K}$. In order to follow the effect of temperature on the composition of zeolites as well as their acidic and textural properties, the desilication of zeolite of $\mathrm{Si} / \mathrm{Al}=164$ with $0.2 \mathrm{M}$ solutions of pure $\mathrm{NaOH}$ and $\mathrm{NaOH} / \mathrm{TBAOH}$ mixture was also performed at $353 \mathrm{~K}$. The obtained results are presented in Table 6 and Fig. 4.

Data presented in Table 6 show that the desilication was more effective at higher temperature: lower values of $\mathrm{Si} / \mathrm{Al}$ were obtained. As mentioned above, at lower temperature of desilication (338 K) Si atoms where preferentially removed from zeolite framework whereas the amount of $\mathrm{Al}$ extracted was negligible. On the other hand, at $353 \mathrm{~K}$ the demetalation was less selective. While the amount of Si extracted is still high (30-49\%) the amount of removed $\mathrm{Al}$ increased significantly (3-4 times) if comparing with $\mathrm{Si}$ and $\mathrm{Al}$ extraction at $338 \mathrm{~K}$.

Low temperature nitrogen adsorption (Table 6 and Fig. 4) showed that both mesopore volume and surface increased when temperature of desilication was raised to $353 \mathrm{~K}$. This effect was especially distinct when pure $\mathrm{NaOH}$ was used. If desilication was done with $\mathrm{NaOH} / \mathrm{TBAOH}$ mixture, the increase of both pore volume and surface was less significant than if pure $\mathrm{NaOH}$ was used. Furthermore, the same effect can be seen in Fig. 4 B, where the mesopores are larger and the pore size distribution is wider

As mentioned in previous Section 3.2.2, the concentration of protonic sites in zeolites desilicated at $338 \mathrm{~K}$ was found to be equal to the concentration of $\mathrm{Al}$ from chemical analysis. It points that the majority of $\mathrm{Al}$ was in tetrahedral framework positions being able to create acidic Si-OH-Al groups. However, in zeolites desilicated at $353 \mathrm{~K}$ with both $\mathrm{NaOH}$ and $\mathrm{NaOH} / \mathrm{TBAOH}$ the concentration of protonic sites was significantly lower than $\mathrm{Al}$ concentration and vital amount of Lewis sites was created. As discussed above, these Lewis acid sites originate from dehydroxylation of the Si-OH-Al situated on mesopore walls according to the mechanism described above (chapter 3.2.4). The surface of mesopores enlargement upon the desilication at $353 \mathrm{~K}$ (if comparing with $338 \mathrm{~K}$ ) implies the extent of dehydroxylation. Similar observation was done by other authors; inter alia Holm et al. [37] reported formation of Lewis acid sites on mesopore walls by dehydroxylation in desilicated zeolites. 
The main aim of desilication is generation of secondary mesoporosity system which improves molecular transport inside zeolite grains. Therefore, the aspect of the accessibility of the acid sites to adsorbate and reactant molecules was subject of our IR studies. The hindered tert-butyl-containing probe pivalonitrile was applied for the first time to the studies of the accessibility of active sites by Trombetta, Busca at al. [38]. Pivalonitrile is not allowed to penetrate micropores of zeolite ZSM-5, therefore it can interact only with the sites situated on the external surface of zeolite crystals, on the surface of mesopores, and in the pore mouths. A powerful method to quantify the remarkably improved accessibility of acid sites in hierarchical zeolites with lutidine and collidine has been delivered by Thibault-Starzyk et al. [25].

The spectra of pivalonitrile sorbed in the parent zeolite and zeolites desilicated with $\mathrm{NaOH}$ solutions are presented in Fig. 5A. Three bands can be distinguished: the doublet 2245 and $2255 \mathrm{~cm}^{-1}$ attributed to pivalonitrile molecules interacting with silanol Si-OH groups, the $2277 \mathrm{~cm}^{-1}$ band of pivalonitrile interacting with Si-OH-Al groups, and the $2305 \mathrm{~cm}^{-1}$ band of pivalonitrile bonded to Lewis acid sites. Sorption of pivalonitrile in the parent ZSM-5 of Si/Al $=164$ resulted in the appearance of the bands of pivalonitrile molecules interacting with Si$\mathrm{OH}$ and with acidic Si-OH-Al. The band of pivalonitrile bonded to Lewis sites was negligible in agreement with the fact that the concentration of these sites was very low $(6 \mu \mathrm{mol} / \mathrm{g}$ - see Table 1). The desilication in diluted $\mathrm{NaOH}(0.1$ and $0.2 \mathrm{M}$ ) resulted in the enhance of mesopore volume (see Table 3) and also in the significant increase of the amount of the Si$\mathrm{OH}$ groups (Fig. 1A) which is reflected as an increase of IR bands of pivalonitrile interacting with Si-OH groups on mesopore walls. What is more important, sorption of pivalonitrile points also to the increase of accessibility of the $\mathrm{Si}-\mathrm{OH}-\mathrm{Al}$ groups in consequence of the mesopores formation. The best accessibility of $\mathrm{Si}-\mathrm{OH}-\mathrm{Al}$ groups to bulky molecules was observed for zeolite treated with $0.1 \mathrm{M} \mathrm{NaOH}$, which showed the highest mesopore surface as well (Table 3). The band of pivalonitrile interacting with Lewis acid sites increased with the extent of desilication, what can be explained by the facile formation of Lewis sites (see Table 1). As mentioned earlier, Lewis sites are supposed to be formed by the dehydroxylation of the protonic sites on mesopore walls, therefore their amount increase with the development of mesopore surface. The highest intensity of the band of pivalonitrile interacting with Lewis sites is observed for zeolite treated with $0.5 \mathrm{M} \mathrm{NaOH}$ which showed also the highest concentration of Lewis sites (Table 1).

The desilication with $\mathrm{NaOH} / \mathrm{TBAOH}$ mixture resulted in the increase of the intensity of the $\mathrm{Si}-\mathrm{OH}$ band corresponding to the generation of the isolated silanols on mesopore 
surface (Fig. 1B). This type of the Si-OH groups is accessible to pivalonitrile molecules what can be reflected as the increase of the bands of pivalonitrile at $2245-2255 \mathrm{~cm}^{-1}$ (Fig. 5 B, C). The intensities of bands of pivalonitrile interacting with Si-OH-Al $\left(2277 \mathrm{~cm}^{-1}\right)$ and with Lewis acid sites $\left(2305 \mathrm{~cm}^{-1}\right)$ do also increase. This effect is especially significant if desilication was done with $0.5 \mathrm{M}$ solutions (Fig. 5C). It should be noted that the concentrations of both Brønsted sites and of Lewis sites in zeolites treated with $\mathrm{NaOH}$ and $\mathrm{NaOH} / \mathrm{TBAOH}$ are comparable, and the surface and volume of mesopores are also similar (see Tables 2 and 3). Therefore, higher intensity of the bands of pivalonitrile interacting with of acid sites of all types may be the result of higher contribution of acid sites situated on mesopore walls in the whole population of these sites in zeolite treated with $\mathrm{NaOH} / \mathrm{TBAOH}$.

The effect of desilication temperature ( $338 \mathrm{~K}$ and $353 \mathrm{~K}$ ) for both desilicating agents (pure $\mathrm{NaOH}$ and $\mathrm{NaOH} / \mathrm{TBAOH}$ mixtures) on the accessibility of the acid sites will be now discussed. For zeolites desilicated with pure $\mathrm{NaOH}$ at $353 \mathrm{~K}$ (Fig. 6A), the bands of pivalonitrile bonded both to Brønsted and Lewis acid sites increased distinctly. It points to the higher accessibility associated with the increase of specific surface area and volume of mesopores (see Table 6). The desilication with pure $\mathrm{NaOH}$ at $353 \mathrm{~K}$ led to substantial increase of number of the Lewis acid sites, probably during dehydroxylation process favoured after modification. On the other hand, when the desilication was performed in presence of $\mathrm{TBA}^{+}$cations (Fig. $6 \mathrm{~B}$ ), the change of desilication temperature from $338 \mathrm{~K}$ to $353 \mathrm{~K}$ did not significantly improve the accessibility of the $\mathrm{Si}-\mathrm{OH}-\mathrm{Al}$ groups to pivalonitrile molecules (the intensity of $2277 \mathrm{~cm}^{-1}$ band did not change). The band of pivalonitrile interacting with Lewis sites increased if comparing with the zeolite treated with $\mathrm{NaOH} / \mathrm{TBAOH}$ at lower temperature what is related to the increase of total Lewis acidity caused by desilication in more severe conditions (Table 6).

\subsection{Catalytic activity of desilicated zeolites}

The catalytic activity of desilicated zeolites was studied in two reactions: cracking of $n$-decane and cracking of 1,3,5-tri-isopropyl benzene (TIPB). Cracking of $n$-decane offers information about intrinsic activity of the zeolites, as molecule has no diffusion limitations when medium and large pore catalysts are considered. In addition to $n$-decane tests cracking of 1,3,5-tri-isopropyl benzene has been carried out. The TIPB molecule is able to enter the 12 MR pores, but is not allowed to access to 10 MR pore such in ZSM-5. Comparison of the results of $n$-decane and TIPB cracking offers possibility to estimate the accessibility of acid sites on the catalyst external surface. The rate constants in these reactions are presented in Table 7. These values are referred to the mesopore volume as well as the concentration of acid 
sites and their acid strength ( $\Delta v_{\mathrm{OH}} . . \mathrm{CO}$ values), which have been already presented in previous chapters (Tables 2 and 5) are repeated for clarity of discussion in Table 7. As mentioned above, desilication almost did not change the concentration of protonic sites, but it affects the acid strength. The drop of acid strength caused by desilication is interpreted as the result of removal of those $\mathrm{Al}$ atoms which are responsible for the formation of the most acidic $\mathrm{Si}-\mathrm{OH}$ Al. This decrease is more significant for zeolite treated with pure $\mathrm{NaOH}$ which extracted more Al than $\mathrm{NaOH} / \mathrm{TBAOH}$ mixture (see Table 2).

Catalytic properties of desilicated zeolites are governed both by acidity of acid sites and their accessibility. The catalytic activity given as TIPB conversion increases in the following order: parent zeolite $<\mathrm{NaOH}$ treated zeolite $<\mathrm{NaOH} / \mathrm{TBAOH}$ mixture treated zeolite, what matches the increase of both the mesopore volume (Table 7) and accessibility of protonic sites (intensity of IR band of pivalonitrile interacting with protonic sites increases Fig. 5B). From the fact that catalytic activity of desilicated zeolites increases with the accessibility of protonic sites, in spite of the decreasing acid strength of sites upon desilication, it can be anticipated that the mesopores system benefits the diffusion of the bulky 1,3,5-tri-isopropyl benzene molecule which provides hierarchical zeolites higher activity. It can be concluded, that accessibility of protonic sites, not their acidity, plays essential role in TIPB cracking.

Different situation was observed for linear $n$-decane molecules, which are allowed to easily penetrate the channels of ZSM-5 zeolite. The data presented in Table 7 indicate the decrease of the catalytic activity in the following order: parent zeolite $>\mathrm{NaOH} / \mathrm{TBAOH}$ treated zeolite $>\mathrm{NaOH}$ treated zeolite, i.e. in the same order as the acid strength of the $\mathrm{Si}-\mathrm{OH}$ $\mathrm{Al}$ groups decreases. On the other hand, the increase of the accessibility of acid sites upon desilication facilitates the diffusion of $n$-decane. All these findings indicate that for linear $n$ decane molecule catalytic activity is ruled by acidity not accessibility of sites in hierarchically structured zeolites.

Higher intensity of the bands of pivalonitrile bonded to protonic sites in zeolites desilicated in the presence of TBAOH strongly evidences higher accessibility of acid sites in this material to bulky molecules (Fig. 5B). Enhanced accessibility of acid sites is reflected in higher ability of TIPB cracking performance, where 1.5-fold increase of the values of firstorder kinetic rate constants is observed for zeolites treated in the presence of TBAOH in comparison to material treated with pure $\mathrm{NaOH}$. 


\section{Conclusions}

1. The results of chemical analysis and XPS analysis showed that desilication of highly siliceous ZSM-5 of $\mathrm{Si} / \mathrm{Al}=164$ was more effective in the surface zone than in the zeolite bulk For zeolite of lower $\mathrm{Si} / \mathrm{Al}=31.6$ [15] desilication was more effective from the bulk, what was explained by the excess of $\mathrm{Al}$ on the surface and the protection of neighboring Si atoms by negative charge of $\mathrm{AlO}_{4}{ }^{-}$against $\mathrm{OH}^{-}$attack. In highly siliceous zeolite of $\mathrm{Si} / \mathrm{Al}=164$ the concentration of $\mathrm{Al}$ was so low that even some excess of $\mathrm{Al}$ atoms in surface zone was not sufficient to protect of surface $\mathrm{Si}$ atoms from $\mathrm{OH}^{-}$ions attack.

2. In parent zeolite the concentration of protonic sites was similar to the concentration of $\mathrm{Al}$ from chemical analysis indicating, that all $\mathrm{Al}$ atoms generate the $\mathrm{Si}-\mathrm{OH}-\mathrm{Al}$ groups. In desilicated zeolites all Al were able to form protonic sites. However, part of them undergoes facile dehydroxylation during the thermal pretreatment of zeolite producing Lewis acid sites. According to the stoichiometry of dehydroxylation process: one protonic site is transformed into one Lewis site.

3. In zeolite treated with more concentrated $\mathrm{NaOH}(0.5 \mathrm{M})$ three categories of $\mathrm{Al}$ species can be discriminated: $\mathrm{Al}$ atoms in $\mathrm{AlO}_{4}{ }^{-}$able to create typical zeolitic Si-OH-Al characterized by $3610 \mathrm{~cm}^{-1}$ band, the $\mathrm{Al}$ atoms on the surfaces of extraframework clusters creating protonic sites but not characterized by $3610 \mathrm{~cm}^{-1}$ band, and finally the $\mathrm{Al}$ atoms forming Lewis acid sites.

4. The acid strength of the Si-OH-Al groups decreases with the extent of desilication, what is explained by the removal of framework $\mathrm{Al}$ responsible for the formation of the most acidic hydroxyls.

5. Low temperature nitrogen adsorption revealed that the treatment of highly siliceous zeolite with $0.2 \mathrm{M} \mathrm{NaOH/TBAOH}$ mixture produced mesopores of small diameter and narrow pore size distribution. Both $\mathrm{Al}$ and $\mathrm{TBA}^{+}$cations act as pore directing agents (PDA) but in the presence of $\mathrm{Al}$ larger pores than for $\mathrm{TBA}^{+}$are formed. In $\mathrm{Al}$-poor zeolite $(\mathrm{Si} / \mathrm{Al}=164)$ the $\mathrm{TBA}^{+}$cations play dominant role as PDA producing narrow pores. Highly siliceous zeolite with uniform distribution of relatively narrow pores may be useful catalyst or catalyst support.

6. The increase of desilication temperature from $338 \mathrm{~K}$ to $353 \mathrm{~K}$ resulted in distinct increase of the mesopore volume and specific surface area due to progressed demetalation (more $\mathrm{Si}$ and $\mathrm{Al}$ is extracted at elevated temperature). The concentration of protonic sites was found to be lower in zeolite desilicated at higher temperature. Due to facile 
dehydroxylation and partial zeolite destruction the amount of Lewis sites raised substantially.

7. The experiments of pivalonitrile sorption followed by IR spectroscopy evidenced a significant increase of accessibility of acid sites to hindered molecules. This effect was more noticeable when desilication was done with $\mathrm{NaOH} / \mathrm{TBAOH}$ mixture.

8. Catalytic activity was found to be depended on both acid strength and accessibility of SiOH-Al groups. For linear $n$-decane molecule without diffusion constrains the catalytic activity is ruled by acid strength of Brønsted sites and it correlates with CO sorption data. whereas the accessibility of sites in hierarchically structured zeolites. On the other hand, for 1,3,5-tri-isopropyl benzene that accessibility of protonic sites enhanced by newly generated porosity plays essential role in TIPB cracking. The 1.5-fold increase of the values of first-order kinetic rate constants was observed for zeolites treated with TBAOH in comparison to material treated with pure $\mathrm{NaOH}$.

\section{Acknowledgment}

This work was supported by the International PhD-studies programme at the Faculty of Chemistry Jagiellonian University within the Foundation for Polish Science MPD Programme co-financed by the EU European Regional Development Fund and by Grant NO. 2011/01/B/ST5/00915 from the National Science Centre, Poland.

The research was partially carried out with the equipment purchased thanks to the financial support of the European Regional Development Fund in the framework of the Polish Innovation Economy Operational Program (contract no. POIG.02.01.00-12-023/08). 


\section{References}

[1] K. Egeblad, C. H. Christensen, M. Kustova, CH. Christensen, Chem. Mater. 20 (2008) 946.

[2] J. C. Groen, J. A. Moulijn, J. Perez-Ramirez, J. Mater. Chem. 16 (2006) 2121.

[3] J. Pérez-Ramírez, C. H. Christensen, K. Egeblad, C. H. Christensend, J.C. Groen, Chem. Soc. Rev. 37 (2008) 2530.

[4] R, Chal, C. Grardin, M. Bulut, S. van Donk, ChemCatChem 3 (2011) 67.

[5] K. Cho, H. S. Cho, L. C. de Menorval, R. Ryoo, Chem. Mater., 21 (2009) 5664.

[6] Y. Song, X. Zhu, Y. Song, Q,. Wang, Appl. Catal. A, 302 (2006) 69.

[7] L. Zhao, B. Shen, J. Gao, C. Xu, J. Catal., 258 (2008) 228.

[8] M. H. F. Knox, E. Stavitski, J. C. Groen, J. Pérez-Ramirez, F. Kapteijn, B. M. Weckhuysen, Chem. Eur. J., 14 (2008) 1718.

[9] C. Mei, P. Wen, Z. Liu, Y. Wang, W. Yang, Z. Xie, W. Hua, Z. Gao, J. Catal., 258 (2008) 243.

[10] J. Kim, M. Choi, R. Ryaoo, J. Catal., 269 (2010) 219.

[11] J. C. Groen, T. Sano, J. A. Mouljin, J. Pérez-Ramirez, J. Catal., 251 (2007) 21.

[12] J. C. Groen, S. Abello, L. A. Villaescusa, J. Pérez-Ramirez, Micropor. Mesopor. Mater., 114 (2008) 93.

[13] A. Bonilla, D. Baudouin, J. Pérez-Ramirez, J. Catal., 265 (2009) 170.

[14] Ł. Mokrzycki, B. Sulikowski, Z. Olejniczak, Catal. Lett., 127 (2009) 196.

[15] K. Sadowska, A. Wach, Z. Olejniczak, P. Kuśtrowski, J. Datka, Microporous Mesoporous Materials, doi: 10.1016/j.micromeso.2012.03.045.

[16] D. Verboekend, J. C. Groen, J. Pérez-Ramirez, Adv. Funct. Mater., 20 (2010) 1441.

[17] D. Verboekend, J. Pérez-Ramirez, Chem. Eur. J. 17 (2011) 1137.

[18] N.S. Nesterenko, F. Thibault-Starzyk, V. Montouillout, V.V. Yuschenko, C. Fernandez, J.-P. Gilson, F. Fajula, I.I. Ivanova, Micropor. Mesopor. Mater. 71 (2004) 157.

[19] S. van Donk, E. Bus, A. Broersma, J.H. Bitter, K.P. de Jong, J. Catal. 212 (2002) 86.

[20] T. Montanari, M. Bevilacqua, G. Busca, Appl. Catal. A 307 (2006) 21.

[21] G. Busca, Chem. Rev. 107 (2007) 5366.

[22] B. Gil, S.I. Zones, S.-J. Hwang, M. Bejblova, J. Cejka, J. Phys. Chem. C 112 (2008) 2997.

[23] V.V. Ordomsky, V.Y. Murzin, Yu.V. Monakhova, Y.V. Zubavichus, E.E. Knyazeva, N.S. Nesterenko, I.I. Ivanova, Micropor. Mesopor. Mater. 105 (2007) 101. 
[24] M.S. Holm, S. Svelle, F. Joensen, P. Beato, C.H. Christensen, S. Bordiga, M. Bjørgen, Appl. Catal. A 356 (2009) 23.

[25] F. Thibault-Starzyk, I. Stan, S. Abello, A. Bonilla, K. Thomas, Ch. Fernandez, J.-.P Gilson, J. Pérez-Ramirez, J. Catal. 264 (2009) 11.

[26] A. Corma, J. Martinez-Triguero, S. Valencia, E. Benazzi, S. Lacombe, J. Catal. 206 (2002) 125.

[27] R. von Ballmoos, W. M. Meier, Nature 289 (1981) 782.

[28] R. Althoff, B. Schultz-Dobrick, F.Schuth, K. K. Unger, Microporous Mater. 1 (1993) 207.

[29] J. Pérez-Ramirez, D. Verboekend, A. Bonilla, S. Abello, Adv. Funct. Mater. 19 (2009) 3972.

[30] K. Sadowska, K. Góra-Marek, J. Datka, Vibrational Spectroscopy, submitted

[31] J. Datka, M. Kawałek, K. Góra-Marek, Applied Catalysis, 243 (2003) 293.

[32] J. Uytterhoeven, L.G. Christner, W.K. Hall, J. Phys. Chem., 69 (1965) 2117.

[33] J. Datka, J.Chem.Soc. Faraday I, 77 (1981) 2877.

[34] K. Góra-Marek, J. Datka, Applied Catalysis A, 302 (2006) 104.

[35] J. C. Groen, L. A. A. Peffer, J. A. Moulijn, J. Pérez-Ramirez, Chem. Eur. J., 11 (2005) 4983.

[36] S. Abello, A. Bonilla, J. Pérez-Ramirez, Applied Catal. A 364 (2009) 191

[37] M. S. Holm, S. Svelle, F. Joensen, P. Beato, C. H. Christensen, S. Bordiga, M. Bjørgen, Appl. Catal. A, 356 (2009) 23.

[38] M. Trombetta, G. Busca, M. Lenarda, L. Storaro, M. Pavan, Appl. Catal. A, 182 (1999) 225. 


\section{Figures Captions}

1. IR spectra of $\mathrm{OH}$ groups.

A - OH groups in parent zeolite and zeolites treated with $0.1 \mathrm{M}, 0.2 \mathrm{M}$ and $0.5 \mathrm{M} \mathrm{NaOH}$.

$\mathrm{B}-\mathrm{OH}$ groups in parent zeolite and zeolites treated with $0.2 \mathrm{M}$ as well as with $\mathrm{NaOH} / \mathrm{TBAOH}$ mixtures with $\mathrm{R}=0.1$ and 0.4 .

$\mathrm{C}-\mathrm{OH}$ groups in parent zeolite and zeolites treated with $0.5 \mathrm{M} \mathrm{NaOH}$ as well as with $\mathrm{NaOH} / \mathrm{TBAOH}$ mixture with $\mathrm{R}=0.1$.

2. The spectra of $\mathrm{CO}$ and $\mathrm{NH}_{4}{ }^{+}$in zeolites: parent (A), desilicated in $0.2 \mathrm{M} \mathrm{NaOH} / \mathrm{TBAOH}$ with $\mathrm{R}=0.4(\mathrm{~B})$ and in $0.5 \mathrm{M} \mathrm{NaOH} / \mathrm{TBAOH}$ with $\mathrm{R}=0.1(\mathrm{C})$

a - zeolite dehydrated at $450 \mathrm{~K}$,

b - zeolite activated at $820 \mathrm{~K}\left(\mathrm{NH}_{3}\right.$ was sorbed at $\left.380 \mathrm{~K}\right)$.

3. Pore size distribution in zeolite treated with $\mathrm{NaOH}$ and $\mathrm{NaOH} / \mathrm{TBAOH}$ mixtures A - parent zeolite and zeolites desilicated with $0.1 \mathrm{M}, 0.2 \mathrm{M}$ and $0.5 \mathrm{M} \mathrm{NaOH}$.

$\mathrm{B}$ - parent zeolite and zeolites desilicated with $0.2 \mathrm{M} \mathrm{NaOH}$ and $0.2 \mathrm{M} \mathrm{NaOH} / \mathrm{TBAOH}$ mixtures with $\mathrm{R}=0.1$ and 0.4. Diagram marked with asterix $(*)$ zeolite of $\mathrm{Si} / \mathrm{Al}=31.6$ desilicated in $0.2 \mathrm{M} \mathrm{NaOH/TBAOH}$ mixture of $\mathrm{R}=0.4$.

$\mathrm{C}$ - parent zeolite and zeolites desilicated with $0.5 \mathrm{M} \mathrm{NaOH}$ and $\mathrm{NaOH} / \mathrm{TBAOH}$ mixture with $\mathrm{R}=0.1$.

4. Pore size distribution in zeolite treated with $0.2 \mathrm{M} \mathrm{NaOH}$ (A) and $0.2 \mathrm{M} \mathrm{NaOH} / \mathrm{TBAOH}$ mixture with $\mathrm{R}=0.4(\mathrm{~B})$ at $338 \mathrm{~K}$ and $353 \mathrm{~K}$.

5. The spectra recorded upon the sorption of pivalonitrile at room temperature (followed by evacuation at room temperature).

A - parent ZSM-5, and zeolite treated with $0.1 \mathrm{M}, 0.2 \mathrm{M}$, and $0.5 \mathrm{M} \mathrm{NaOH}$.

$\mathrm{B}$ - parent zeolite and zeolite treated with $0.2 \mathrm{M} \mathrm{NaOH}$ and $\mathrm{NaOH} / \mathrm{TBAOH}$ mixtures with $\mathrm{R}$ $=0.1$ and 0.4 .

$\mathrm{C}$ - parent zeolite and zeolite treated with $0.5 \mathrm{M} \mathrm{NaOH}$ and $\mathrm{NaOH} / \mathrm{TBAOH}$ mixture with $\mathrm{R}=$ 0.1 . 
6. The spectra recorded upon the sorption of pivalonitrile at room temperature (followed by evacuation at room temperature) in zeolite desilicated at $338 \mathrm{~K}$ and $353 \mathrm{~K}$ with $\mathrm{NaOH}$ (A) and $\mathrm{NaOH} / \mathrm{TBAOH}$ mixture of $\mathrm{R}=0.4$ (B) 
Fig. 1

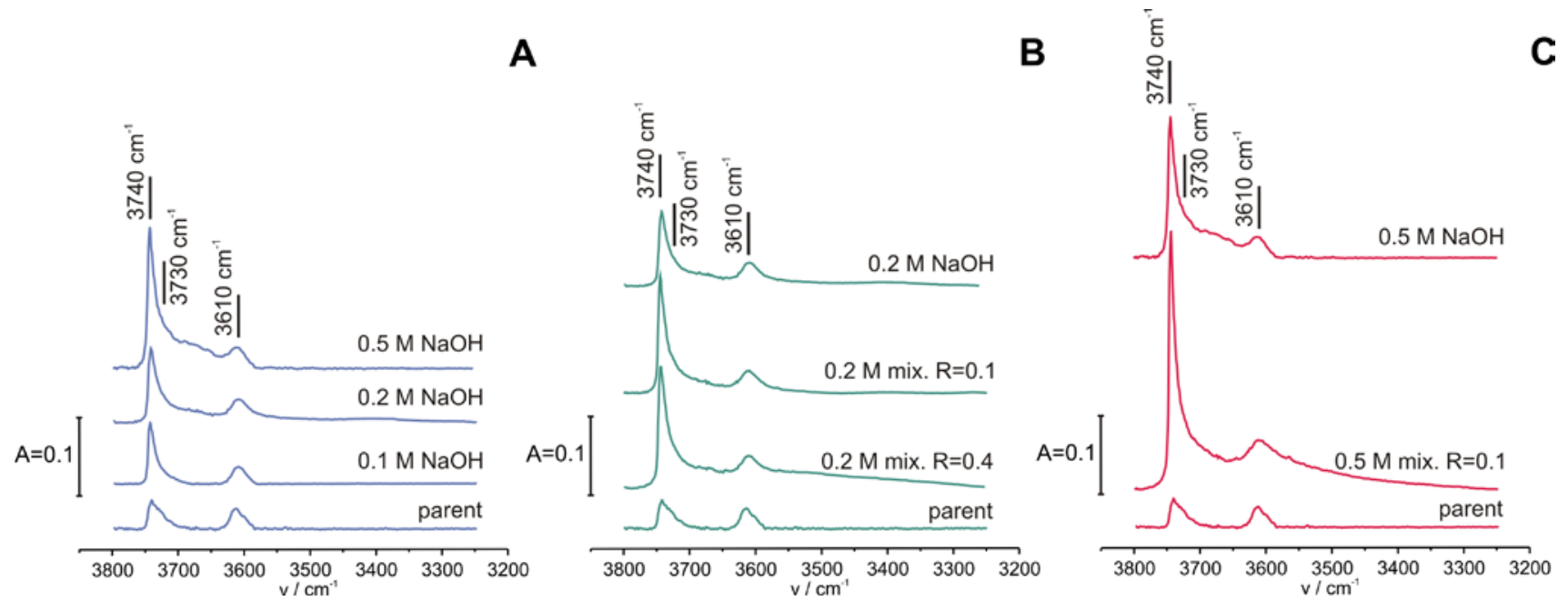


Fig. 2
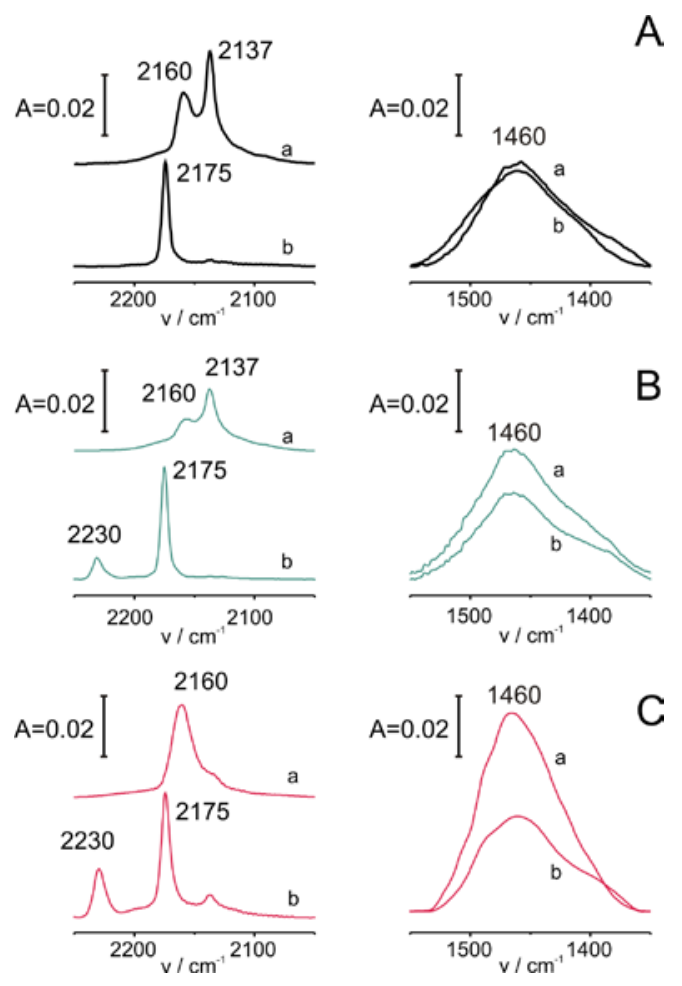
Fig. 3 - horizontal
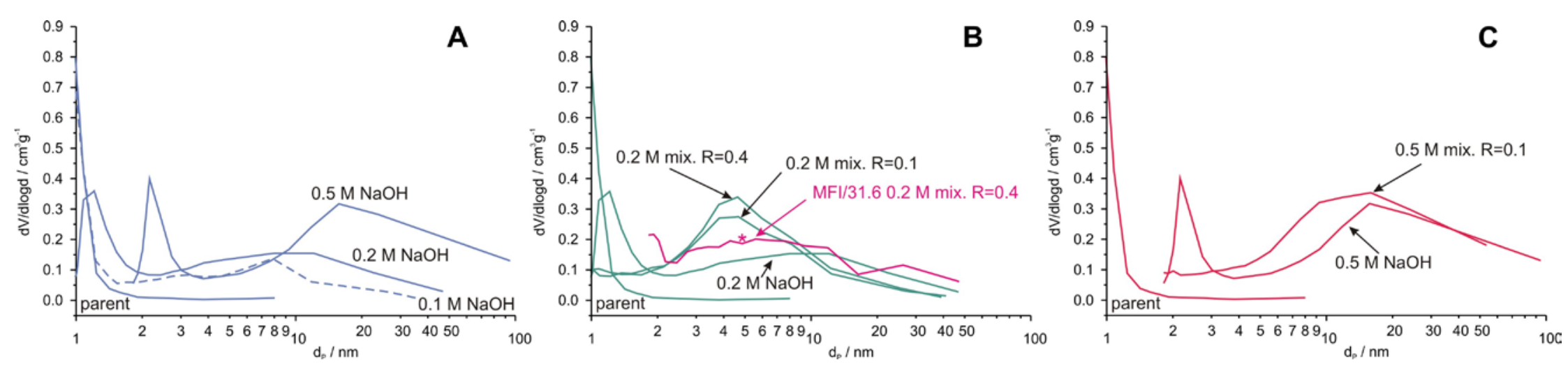
Fig. 3 - vertical
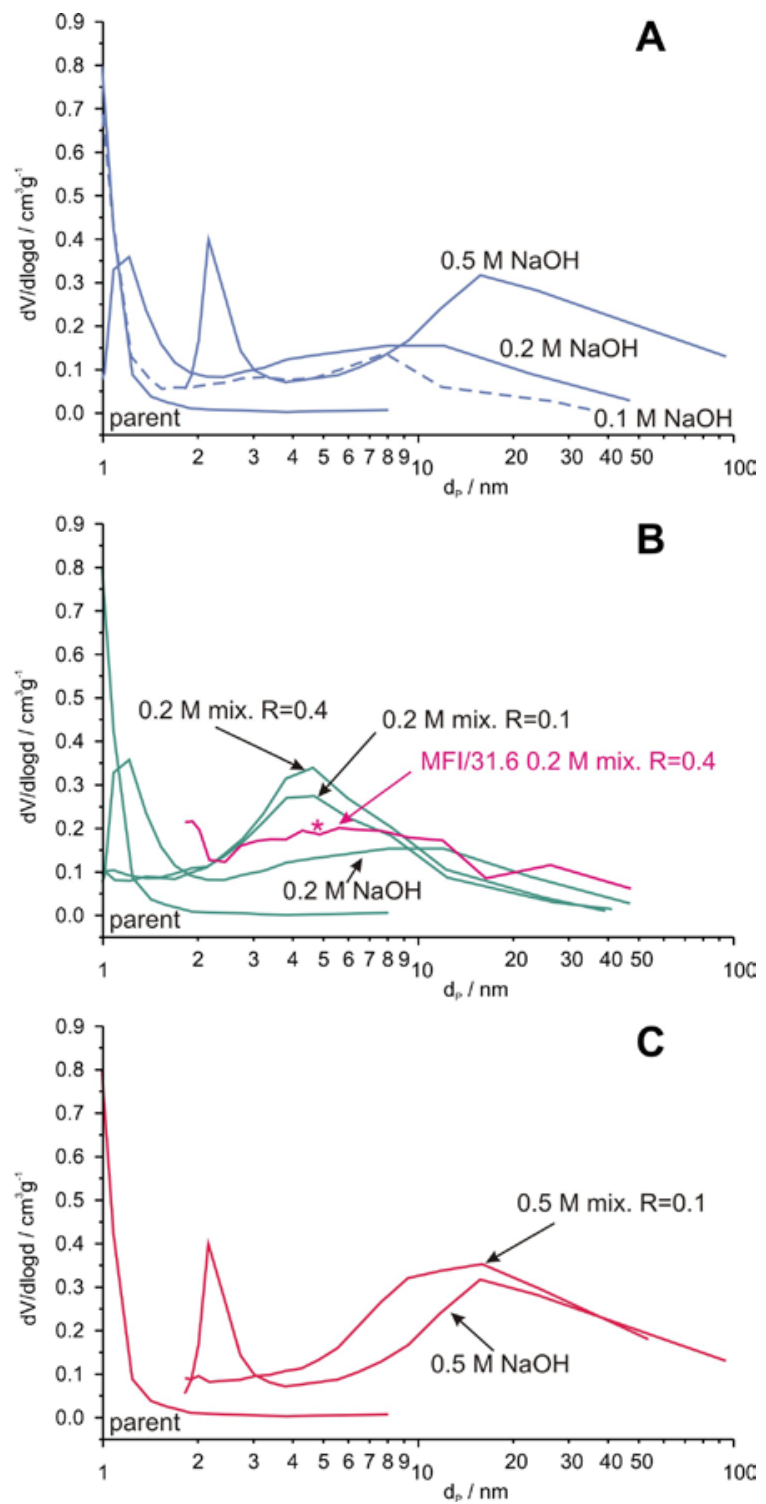
Fig. 4
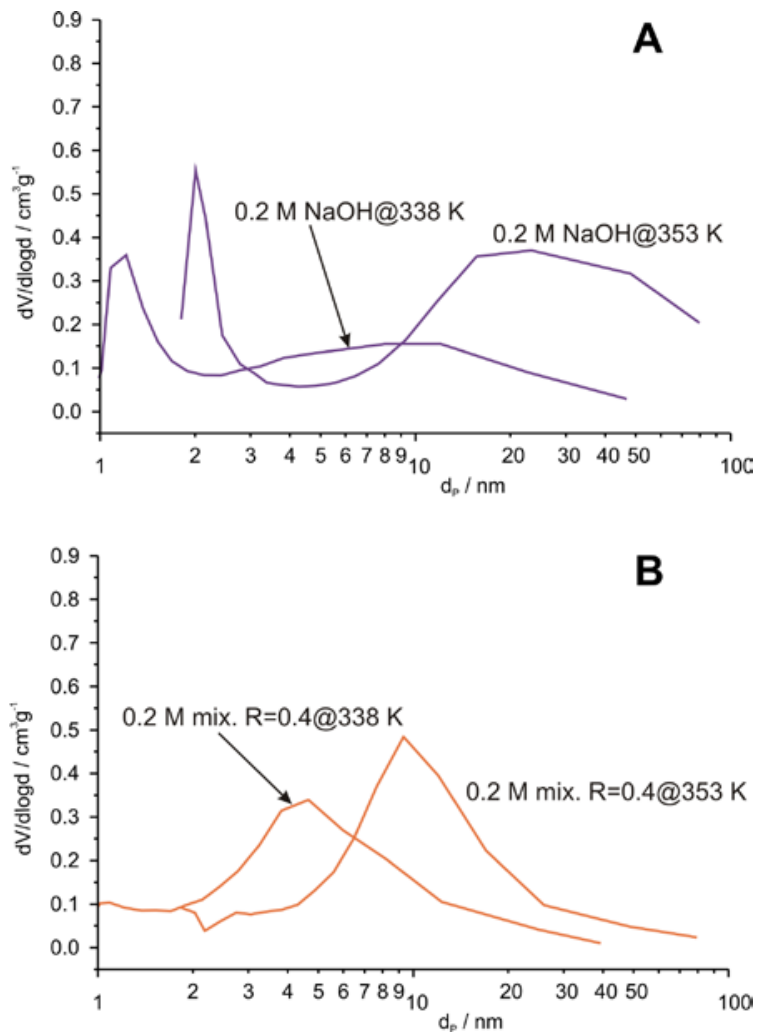
Fig. 5
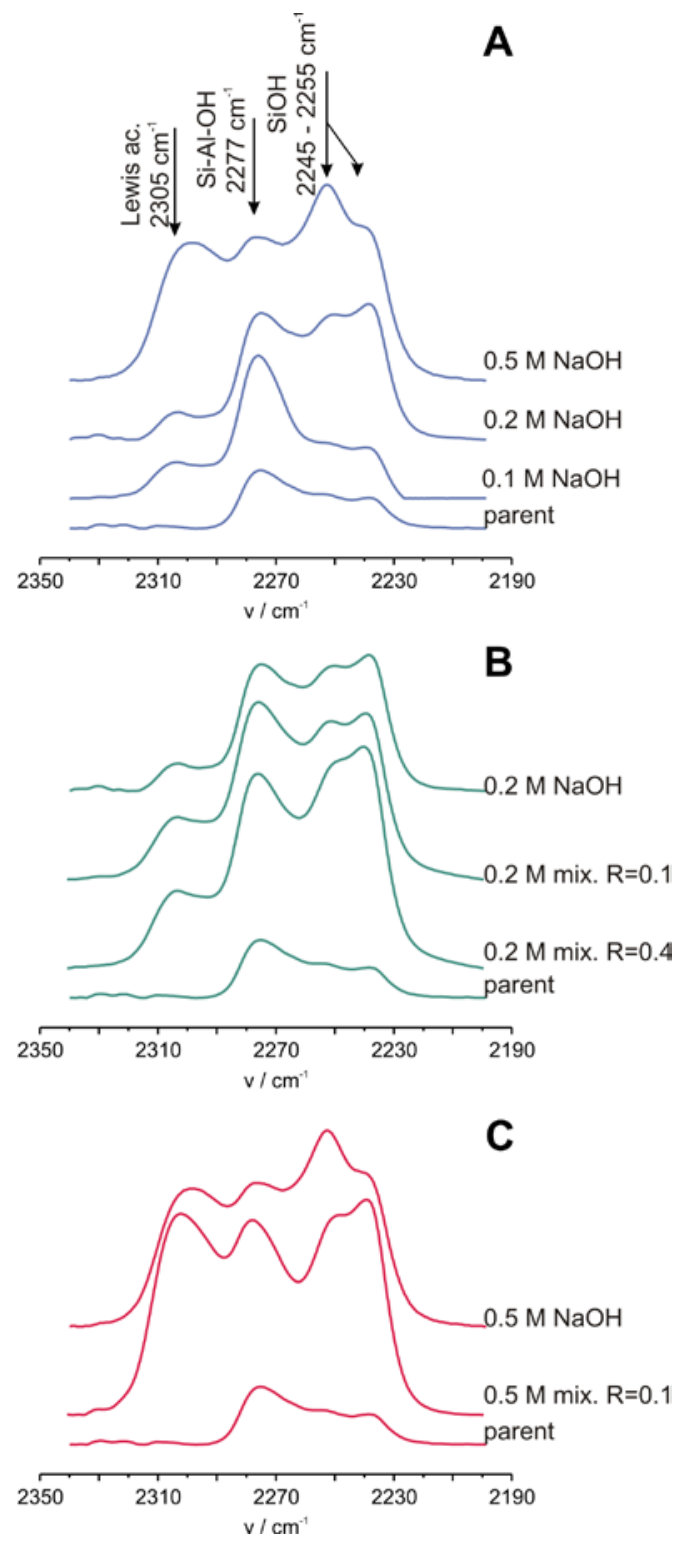
Fig. 6
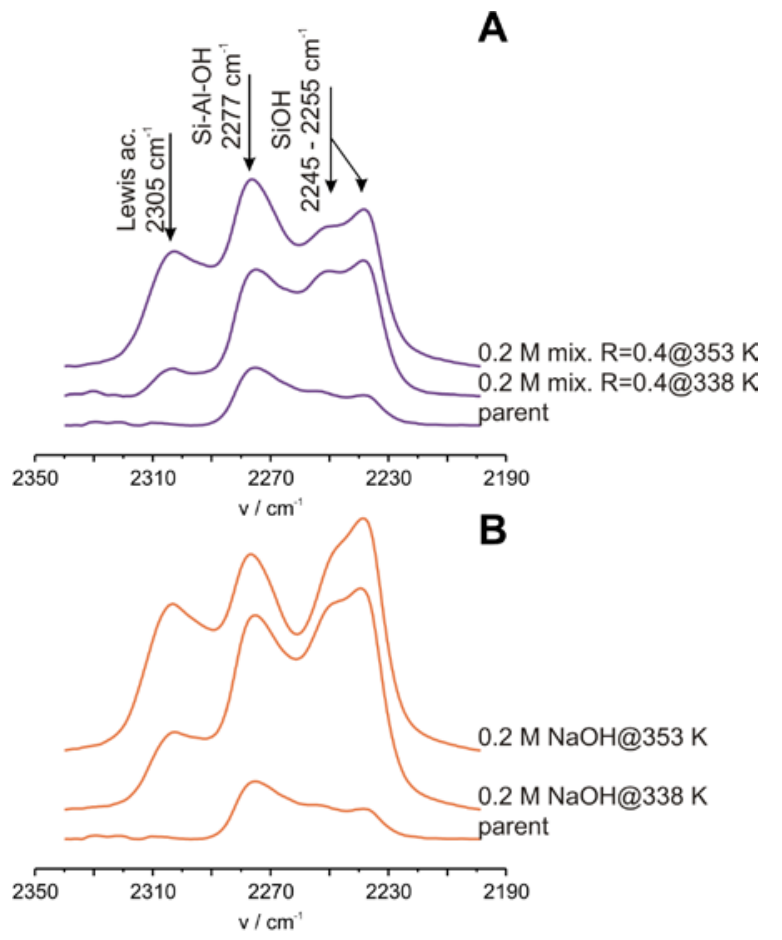


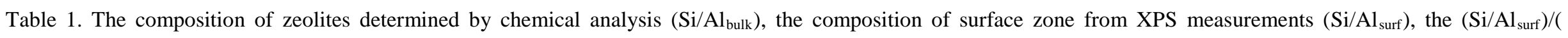
$\mathrm{Si} / \mathrm{Al}_{\text {bulk }}$ ) factor, the \% of $\mathrm{Si}$ and $\mathrm{Al}$ extracted during desilication, the concentration of $\mathrm{Al}$ atoms from chemical analysis, the relative crystallinity value (\%Cryst), the concentration of Brønsted (B. s.) and Lewis acid sites (L. s.) from IR spectroscopy measurements and the acid strength of Si-OH-Al groups (expressed by $\Delta v_{\mathrm{O}-\mathrm{H} . . . \mathrm{CO})}$ in zeolite desilicated with $\mathrm{NaOH}$ of various concentrations.

\begin{tabular}{|c|c|c|c|c|c|c|c|c|c|c|c|}
\hline \multirow{2}{*}{$\begin{array}{l}\text { Concentration of } \\
\mathrm{NaOH}[\mathrm{M}]\end{array}$} & \multirow{2}{*}{$\mathrm{Si} / \mathrm{Al}_{\text {bulk }}$} & \multirow{2}{*}{$\mathrm{Si} / \mathrm{Al}_{\text {surf }}$} & \multirow{2}{*}{$\begin{array}{l}\left(\mathrm{Si} / \mathrm{Al}_{\text {surf }}\right) / \\
\left(\mathrm{Si} / \mathrm{Al}_{\text {bulk }}\right)\end{array}$} & \multirow{2}{*}{$\% \mathrm{Si}_{\text {extr }}$} & \multirow{2}{*}{$\% \mathrm{Al}_{\text {extr }}$} & \multirow{2}{*}{ \%Cryst } & \multicolumn{4}{|c|}{ Concentration $\left[\mu \mathrm{mol} \cdot \mathrm{g}^{-1}\right]$} & \multirow{2}{*}{$\begin{array}{c}\Delta v_{\mathrm{O}-\mathrm{H} . . . \mathrm{CO}} \\
{\left[\mathrm{cm}^{-1}\right]}\end{array}$} \\
\hline & & & & & & & $\mathrm{Al}$ & B. s. & L. S. & $\mathrm{B}+\mathrm{L}$ & \\
\hline Parent & 164 & 134 & 0,82 & 0 & 0 & 100 & 94 & 85 & 6 & 91 & 320 \\
\hline 0.1 & 145 & 73 & 0,50 & 14 & 4 & 100 & 106 & 68 & 16 & 84 & 316 \\
\hline 0.2 & 123 & 56 & 0,44 & 36 & 5 & 92 & 124 & 96 & 28 & 124 & 310 \\
\hline 0.5 & 48 & 20 & 0.41 & 93 & 73 & 65 & 316 & 142 & 145 & 287 & 307 \\
\hline
\end{tabular}


Table 2. The composition of zeolites determined by chemical analysis ( $\mathrm{Si} / \mathrm{Al}_{\text {bulk }}$ ), the composition of surface zone from XPS measurements $\left(\mathrm{Si} / \mathrm{Al}_{\text {surf }}\right)$, the $\left(\mathrm{Si} / \mathrm{Al}_{\text {surf }}\right) /($ $\mathrm{Si} / \mathrm{Al}_{\text {bulk }}$ ) factor, the \% of $\mathrm{Si}$ and $\mathrm{Al}$ extracted during desilication, the concentration of Al atoms from chemical analysis, the concentration of Brønsted (B. s.) and Lewis acid

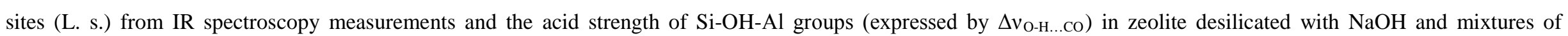
$\mathrm{NaOH} / \mathrm{TBAOH}$ of various concentrations and different $\mathrm{TBAOH} /(\mathrm{NaOH}+\mathrm{TBAOH})$ ratios.

\begin{tabular}{|c|c|c|c|c|c|c|c|c|c|c|c|c|}
\hline \multirow{2}{*}{$\begin{array}{l}\text { Concentration of } \\
\text { bases }[\mathrm{M}]\end{array}$} & \multirow{2}{*}{$\begin{array}{c}\text { TBAOH/ } \\
(\mathrm{TBAOH}+\mathrm{NaOH})\end{array}$} & \multirow{2}{*}{$\mathrm{Si} / \mathrm{Al}_{\text {bulk }}$} & \multirow{2}{*}{$\mathrm{Si} / \mathrm{Al}_{\text {surf }}$} & \multirow{2}{*}{$\begin{array}{l}\left(\mathrm{Si} / \mathrm{Al}_{\text {surf }}\right) / \\
\left(\mathrm{Si} / \mathrm{Al}_{\text {bulk }}\right)\end{array}$} & \multirow{2}{*}{$\% \mathrm{Si}_{\text {extr }}$} & \multirow{2}{*}{$\% \mathrm{Al}_{\text {extr }}$} & \multirow{2}{*}{ \%Cryst } & \multicolumn{4}{|c|}{ Concentration $\left[\mu \mathrm{mol} \cdot \mathrm{g}^{-1}\right]$} & \multirow{2}{*}{$\begin{array}{c}\Delta v_{\mathrm{O}-\mathrm{H}} \ldots \mathrm{CO} \\
{\left[\mathrm{cm}^{-1}\right]}\end{array}$} \\
\hline & & & & & & & & $\mathrm{Al}$ & B. s. & L. S. & $\mathrm{B}+\mathrm{L}$ & \\
\hline \multirow{4}{*}{0.2} & parent & 164 & 134 & 0.82 & 0 & 0 & 100 & 94 & 91 & 6 & 91 & 320 \\
\hline & 0.4 & 123 & 84 & 0.68 & 19 & 2 & 88 & 124 & 102 & 31 & 133 & 316 \\
\hline & 0.1 & 127 & 91 & 0.71 & 18 & 2 & 95 & 121 & 85 & 25 & 110 & 312 \\
\hline & $\mathrm{NaOH}$ & 123 & 56 & 0.44 & 36 & 5 & 92 & 124 & 96 & 28 & 124 & 310 \\
\hline \multirow{3}{*}{0.5} & parent & 164 & 134 & 0.82 & 0 & 0 & 100 & 94 & 91 & 6 & 97 & 320 \\
\hline & 0.1 & 67 & 33 & 0.49 & 78 & 48 & 75 & 227 & 136 & 126 & 262 & 313 \\
\hline & $\mathrm{NaOH}$ & 48 & 20 & 0.41 & 93 & 73 & 64 & 316 & 142 & 145 & 287 & 307 \\
\hline
\end{tabular}


Table 3. The textural parameters of zeolites desilicated with $\mathrm{NaOH}$ of various concentrations.

\begin{tabular}{cccc}
\hline Concentration of $\mathrm{NaOH}[\mathrm{M}]$ & $\begin{array}{c}\mathrm{S}_{\text {meso }} \\
{\left[\mathrm{m}^{2} \cdot \mathrm{g}^{-1}\right]}\end{array}$ & $\begin{array}{c}\mathrm{V}_{\text {meso }} \\
{\left[\mathrm{cm}^{3} \cdot \mathrm{g}^{-1}\right]}\end{array}$ & $\begin{array}{c}\mathrm{V}_{\text {micro }} \\
{\left[\mathrm{cm}^{3} \cdot \mathrm{g}^{-1}\right]}\end{array}$ \\
\hline parent & 140 & 0.082 & 0.104 \\
0.1 & 181 & 0.169 & 0.099 \\
0.2 & 156 & 0.227 & 0.114 \\
0.5 & 164 & 0.287 & 0.106 \\
\hline
\end{tabular}


Table 4. Concentration of $\mathrm{Al}$ and $\mathrm{NH}_{4}{ }^{+}$in zeolite dehydrated at $450 \mathrm{~K}$ and activated at $823 \mathrm{~K}$, loss of $\mathrm{H}^{+}$during activation and the amount of Lewis acid sites in parent zeolite and zeolites desilicated in mixtures of $\mathrm{NaOH} / \mathrm{TBAOH}$.

\begin{tabular}{|c|c|c|c|c|c|}
\hline & \multirow{2}{*}{$\begin{array}{l}\text { Concentration of } \\
\mathrm{Al}\left[\mu \mathrm{mol} \cdot \mathrm{g}^{-1}\right]\end{array}$} & \multicolumn{2}{|c|}{$\begin{array}{l}\text { Concentration of } \\
\mathrm{NH}_{4}^{+}\left[\mu \mathrm{mol} \cdot \mathrm{g}^{-1}\right]\end{array}$} & \multirow{2}{*}{$\begin{array}{l}\text { Loss of } \mathrm{H}^{+} \\
{\left[\mu \mathrm{mol} \cdot \mathrm{g}^{-1}\right]}\end{array}$} & \multirow{2}{*}{$\begin{array}{c}\text { Concentration of } \\
\text { Lewis acid sites } \\
{\left[\mu \mathrm{mol} \cdot \mathrm{g}^{-1}\right]}\end{array}$} \\
\hline & & $\begin{array}{c}\text { before } \\
\text { activation }\end{array}$ & $\begin{array}{c}\text { after } \\
\text { activation }\end{array}$ & & \\
\hline parent & 96 & 94 & 94 & 0 & 6 \\
\hline $\begin{array}{c}0.2 \mathrm{M} \text { mixture } \\
\mathrm{NaOH} / \mathrm{TBAOH}(\mathrm{R}=0.4)\end{array}$ & 115 & 122 & 94 & 28 & 31 \\
\hline $\begin{array}{c}0.5 \mathrm{M} \text { mixture } \\
\mathrm{NaOH} / \mathrm{TBAOH}(\mathrm{R}=0.1)\end{array}$ & 210 & 230 & 104 & 126 & 126 \\
\hline
\end{tabular}


Table 5. The textural parameters of zeolites desilicated with $\mathrm{NaOH}$ and $\mathrm{NaOH} / \mathrm{TBAOH}$ of various concentrations and different $\mathrm{TBAOH} /(\mathrm{NaOH}+\mathrm{TBAOH})$ ratios.

\begin{tabular}{ccccc}
\hline Concentration of bases $[\mathrm{M}]$ & $\begin{array}{c}\mathrm{TBAOH} / \\
(\mathrm{TBAOH}+\mathrm{NaOH})\end{array}$ & $\begin{array}{c}\mathrm{S}_{\text {meso }} \\
{\left[\mathrm{m}^{2} \cdot \mathrm{g}^{-1}\right]}\end{array}$ & $\begin{array}{c}\mathrm{V}_{\text {meso }} \\
{\left[\mathrm{cm}^{3} \cdot \mathrm{g}^{-1}\right]}\end{array}$ & $\begin{array}{c}\mathrm{V}_{\text {micro }} \\
{\left[\mathrm{cm}^{3} \cdot \mathrm{g}^{-1}\right]}\end{array}$ \\
\hline \multirow{3}{*}{0.2} & parent & 140 & 0.082 & 0.104 \\
& 0.4 & 134 & 0.243 & 0.100 \\
& 0.1 & 124 & 0.212 & 0.087 \\
& $\mathrm{NaOH}$ & 156 & 0.227 & 0.114 \\
\hline \multirow{3}{*}{0.5} & parent & 140 & 0.082 & 0.104 \\
& 0.1 & 148 & 0.324 & 0.081 \\
& $\mathrm{NaOH}$ & 164 & 0.287 & 0.106 \\
\hline
\end{tabular}


Table 6. The composition of zeolites determined by chemical analysis ( $\left.\mathrm{Si} / \mathrm{Al}_{\text {bulk }}\right)$, the composition of surface zone from XPS measurements ( $\left.\mathrm{Si} / \mathrm{Al}_{\text {surf }}\right)$, the (Si/Al $\left.\mathrm{Aurf}_{\text {surf }}\right)(\mathrm{f}$ $\mathrm{Si} / \mathrm{Al}_{\text {bulk }}$ ) factor, the \% of Si and $\mathrm{Al}$ extracted during desilication, the concentration of Al atoms from chemical analysis, the concentration of Brønsted (B. s.) and Lewis acid sites (L. s.) from IR spectroscopy measurements and porosimetric data of zeolites desilicated with $\mathrm{NaOH}$ and $\mathrm{NaOH} / \mathrm{TBAOH}$ at different temperatures.

\begin{tabular}{|c|c|c|c|c|c|c|c|c|c|c|c|}
\hline \multirow[b]{2}{*}{ Concentration of bases } & \multirow{2}{*}{$\begin{array}{c}\text { Temperature } \\
{[\mathrm{K}]}\end{array}$} & \multirow[b]{2}{*}{$\mathrm{Si} / \mathrm{Al}_{\text {bulk }}$} & \multirow[b]{2}{*}{$\% \mathrm{Si}_{\text {extr }}$} & \multirow[b]{2}{*}{$\% \mathrm{Al}_{\text {extr }}$} & \multicolumn{4}{|c|}{ Concentration $\left[\mu \mathrm{mol} \cdot \mathrm{g}^{-1}\right]$} & \multicolumn{3}{|c|}{ Porosimetric data } \\
\hline & & & & & $\mathrm{Al}$ & B. s. & L. s. & $\mathrm{B}+\mathrm{L}$ & $\begin{array}{c}\mathrm{S}_{\text {meso }} \\
{\left[\mathrm{m}^{2} \cdot \mathrm{g}^{-1}\right]}\end{array}$ & $\begin{array}{c}\mathrm{V}_{\text {meso }} \\
{\left[\mathrm{cm}^{3} \cdot \mathrm{g}^{-1}\right]}\end{array}$ & $\begin{array}{c}\mathrm{V}_{\text {micro }} \\
{\left[\mathrm{cm}^{3} \cdot \mathrm{g}^{-1}\right]}\end{array}$ \\
\hline Parent & - & 164 & 0 & 0 & 94 & 85 & 6 & 91 & 140 & 0.082 & 0.104 \\
\hline & 338 & 123 & 36 & 5 & 124 & 96 & 28 & 124 & 156 & 0.227 & 0.114 \\
\hline $0.2 \mathrm{M} \mathrm{NaOH}$ & 353 & 95 & 49 & 20 & 149 & 96 & 60 & 156 & 201 & 0.385 & 0.101 \\
\hline $0.2 \mathrm{M}$ mixture & 338 & 123 & 18 & 2 & 124 & 102 & 31 & 133 & 134 & 0.243 & 0.100 \\
\hline $\mathrm{NaOH} / \mathrm{TBAOH}(\mathrm{R}=0.4)$ & 353 & 110 & 30 & 6 & 139 & 96 & 63 & 159 & 140 & 0.279 & 0.100 \\
\hline
\end{tabular}


Table 7. The First-Order Kinetic Rate Constants in catalytic cracking of $n$-decane and 1,3,5-tri-isopropylbenzene (TIPB) for desilicated zeolites. The data on acidity: concentration of Brønsted acid sites and acid strength $\left(\Delta v_{\mathrm{OH} . . . \mathrm{CO}}\right)$ and mesopore volume are taken from Table 2 and Table 5.

\begin{tabular}{|c|c|c|c|c|c|}
\hline \multirow{3}{*}{ Concentration of bases } & \multirow{2}{*}{\multicolumn{2}{|c|}{$\begin{array}{l}\text { First-Order Kinetic Rate Constants in } \\
\text { the Cracking } n \text {-Decane and TIPB } \\
\left.\qquad \text { goil }^{-1} \text { cat }^{-1}\right]\end{array}$}} & \multicolumn{2}{|c|}{ Acidity } & \multirow{3}{*}{$\begin{array}{c}\mathrm{V}_{\text {meso }} \\
{\left[\mathrm{cm}^{3} \cdot \mathrm{g}^{-1}\right]}\end{array}$} \\
\hline & & & \multirow{2}{*}{$\begin{array}{l}\text { Concentration of } \\
\text { B. s. }\left[\mu \mathrm{mol} \cdot \mathrm{g}^{-1}\right]\end{array}$} & \multirow{2}{*}{$\begin{array}{c}\Delta v_{\mathrm{O}-\mathrm{H} . . . \mathrm{CO}} \\
{\left[\mathrm{cm}^{-1}\right]}\end{array}$} & \\
\hline & n-Decane & TIPB & & & \\
\hline Parent & 0.0112 & 0.0149 & 91 & 320 & 0.082 \\
\hline $0.2 \mathrm{M} \mathrm{NaOH}$ & 0.0077 & 0.0263 & 96 & 310 & 0.227 \\
\hline $\begin{array}{c}0.2 \mathrm{M} \text { mixture } \\
\mathrm{NaOH} / \mathrm{TBAOH}(\mathrm{R}=0.4)\end{array}$ & 0.0082 & 0.0361 & 102 & 316 & 0.243 \\
\hline
\end{tabular}




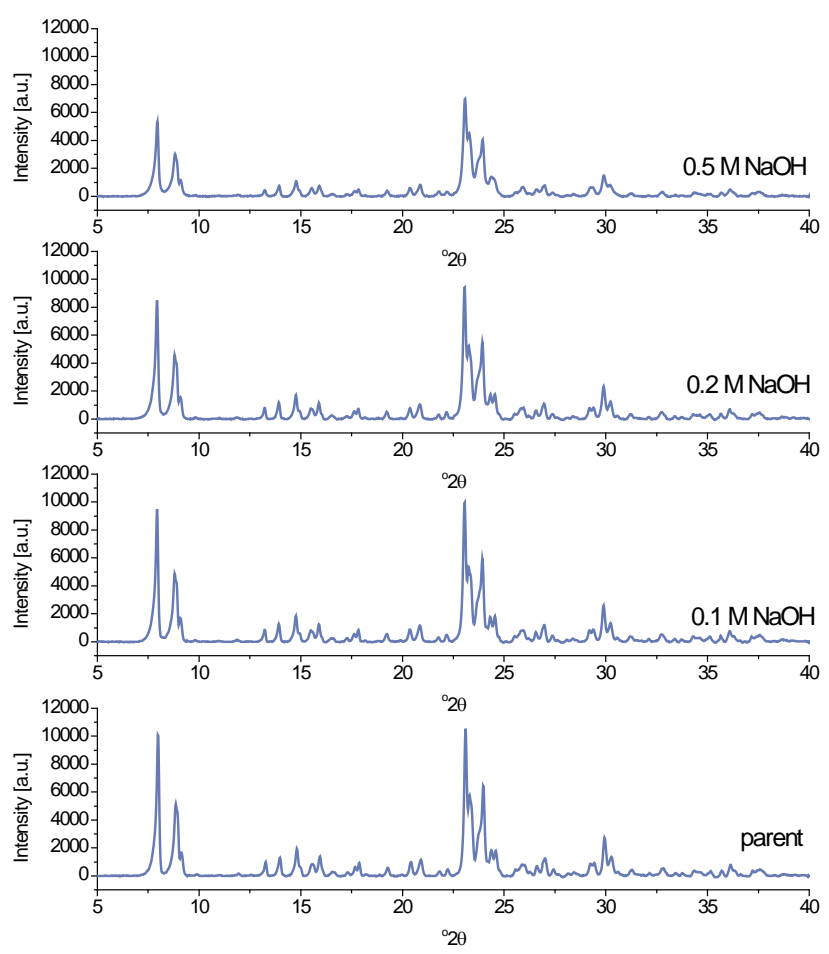

Fig.SI_01. XRD patterns for parent ZSM-5 and the samples treated with $\mathrm{NaOH}$

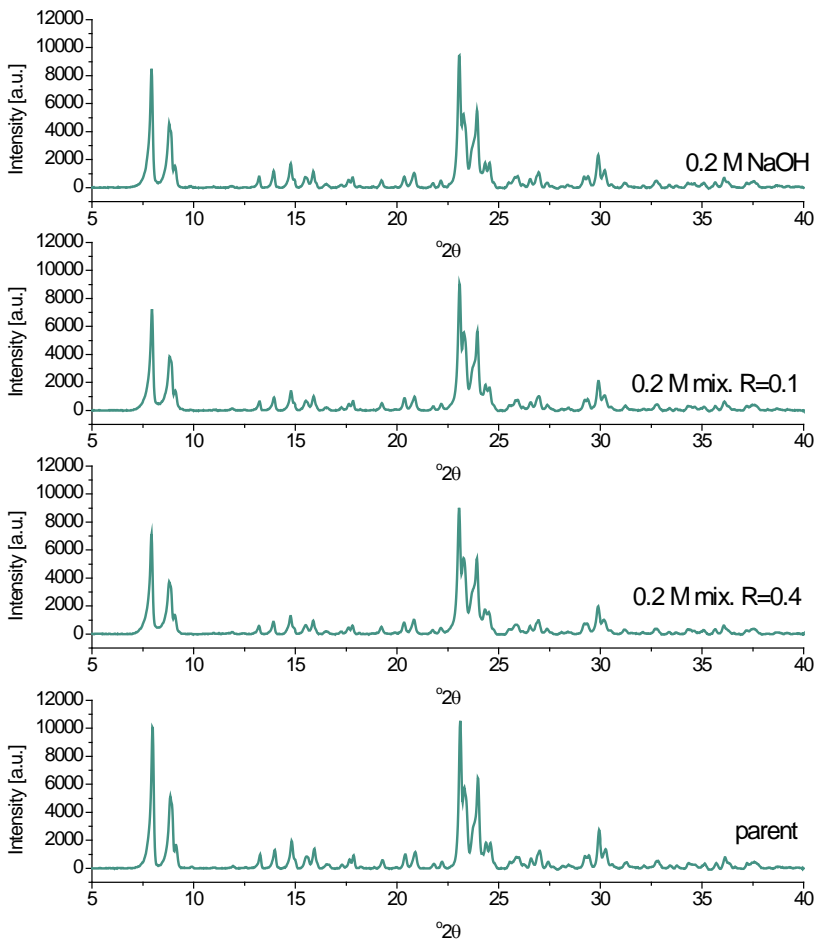

Fig.SI_02. XRD patterns for parent ZSM-5 and the samples treated with $\mathrm{NaOH}$ and $\mathrm{NaOH} / \mathrm{TBAOH}$ mixtures at total base concentration of $0.2 \mathrm{M}$. The $\mathrm{R}=\mathrm{TBAOH} /(\mathrm{NaOH}+\mathrm{TBAOH})$ ratios were 0.1 and 0.4 

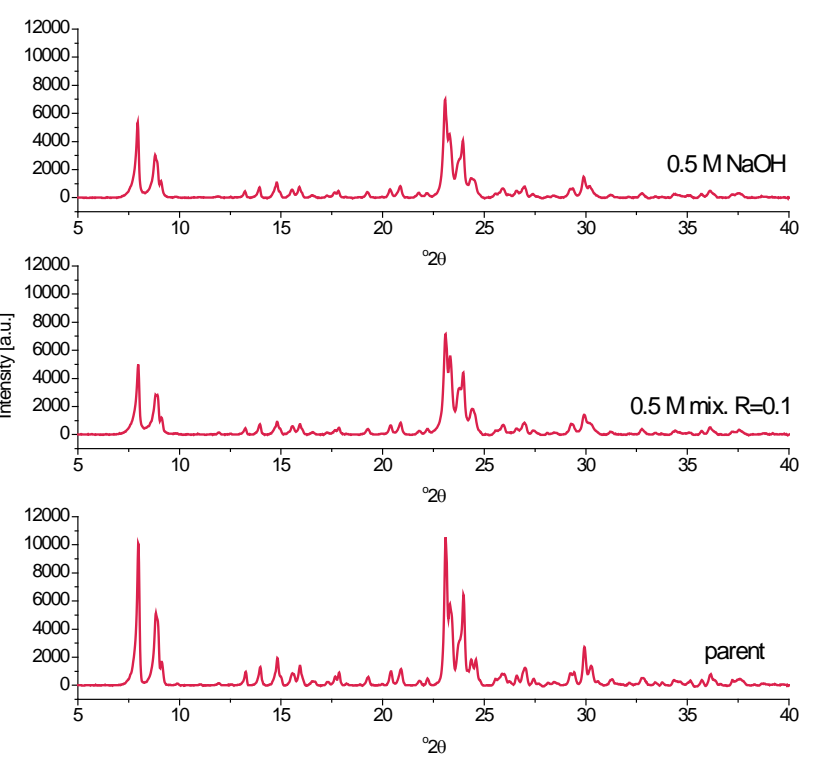

Fig._SI_03. XRD patterns for parent ZSM-5 and the samples treated with $\mathrm{NaOH}$ and $\mathrm{NaOH} / \mathrm{TBAOH}$ mixture at total base concentration of $0.5 \mathrm{M}$. The $\mathrm{R}=\mathrm{TBAOH} /(\mathrm{NaOH}+\mathrm{TBAOH})$ ratio was 0.1
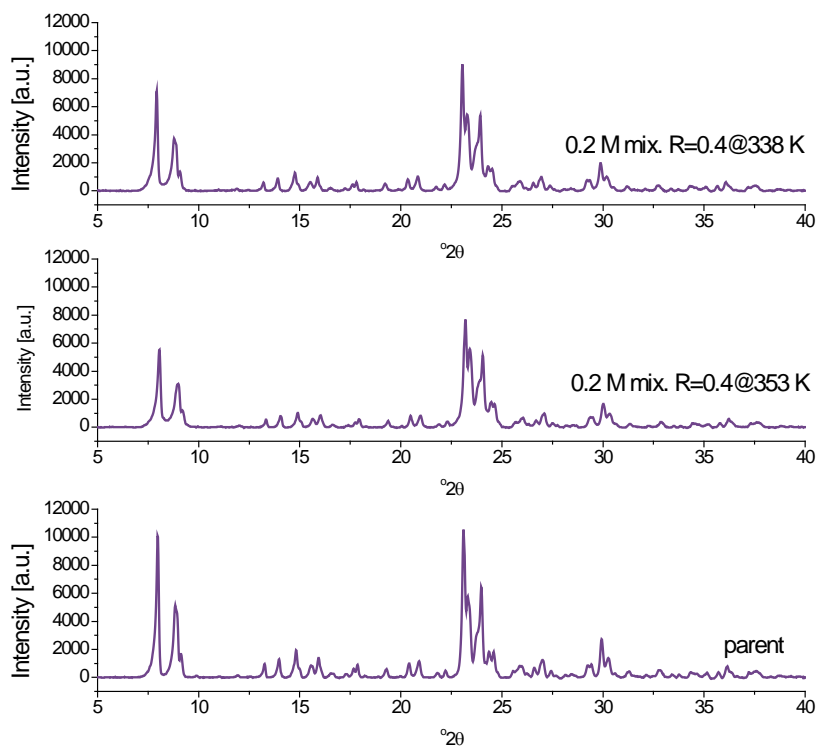

Fig._SI_04. XRD patterns for parent ZSM-5 and the samples treated with0.2 M NaOH/TBAOH mixture at two different temperatures: $338 \mathrm{~K}$ and $353 \mathrm{~K}$ 

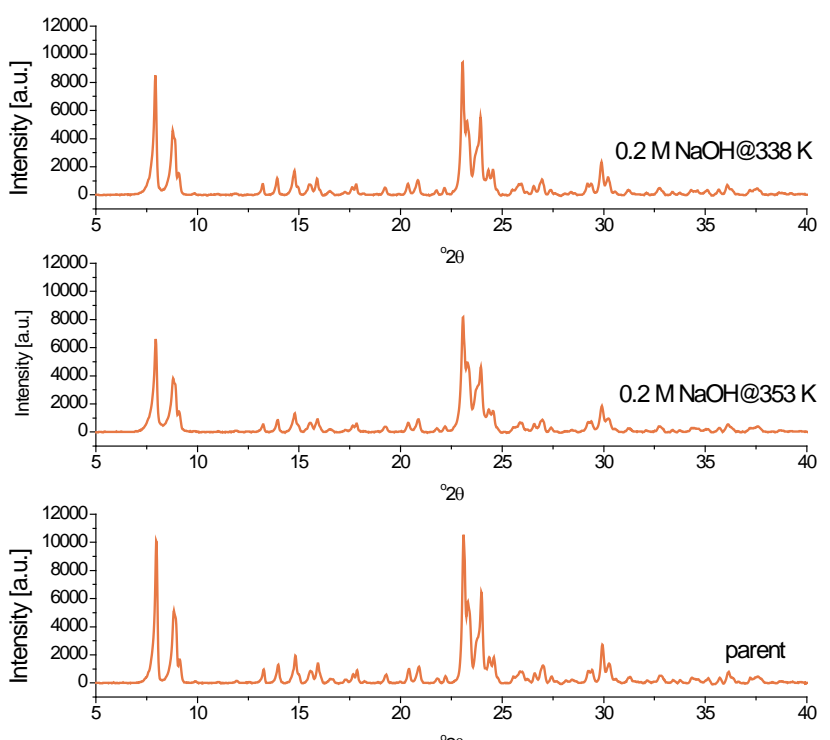

Fig._SI_05. XRD patterns for parent ZSM-5 and the samples treated with $0.2 \mathrm{M} \mathrm{NaOH}$ at two different temperatures: $338 \mathrm{~K}$ and $353 \mathrm{~K}$ 


\section{The three types of $\mathrm{OH}$ groups in desilicated ZSM-5 - evidence for realumination}

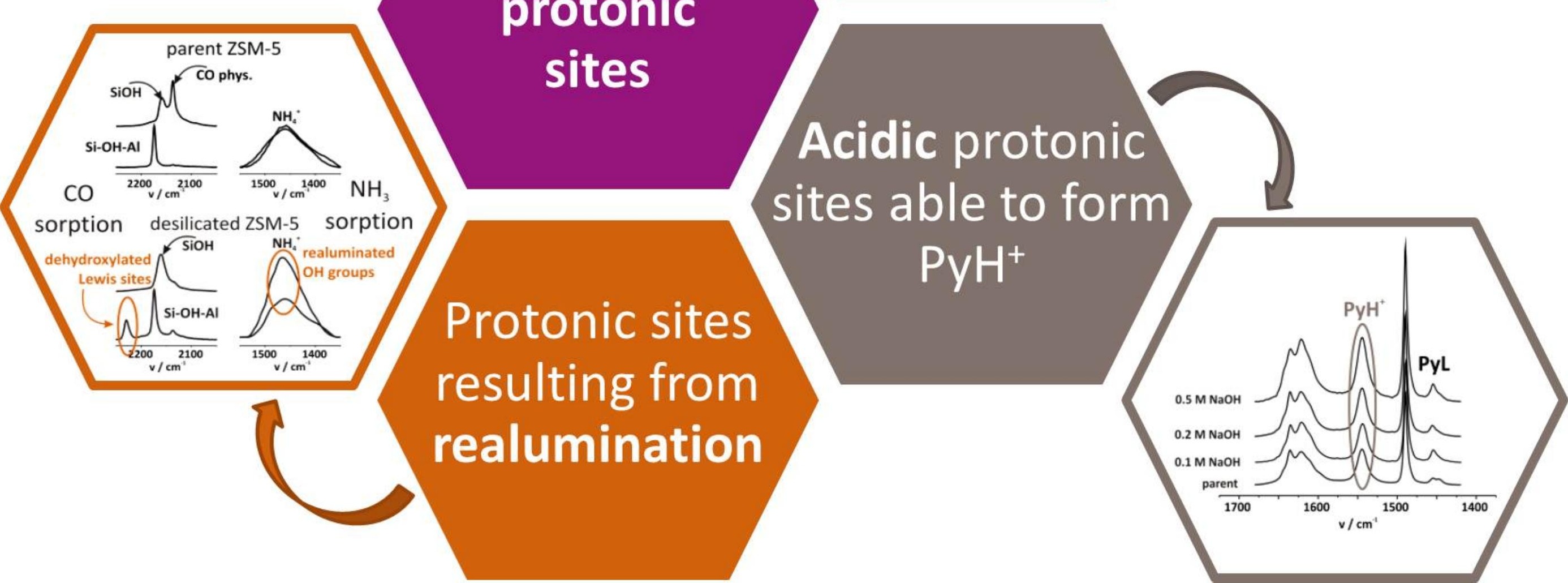


In ZSM-5 (Si/Al=164) Si removal is more effective in surface than in bulk.

Desilication of highly siliceous ZSM-5 produces relatively narrow mesopores.

$\mathrm{Al}$ removed by $\mathrm{NaOH}$ is reinserted into mesopore walls producing new Si-OH-Al.

New hydroxyls are very prone for dehydroxylation during thermal treatment. 